University of Tennessee Health Science Center

UTHSC Digital Commons

\title{
$5-2011$
}

\section{Inhibition of Monocyte Chemotaxis and Chemokine Macrophage Inflammatory Protein-1 Alpha, and Interleukin-8 Secretion by Lipopolysaccharide Isolated from Periodontal Pathogens}

Andrew Karl Gray

University of Tennessee Health Science Center

Follow this and additional works at: https://dc.uthsc.edu/dissertations

Part of the Periodontics and Periodontology Commons

\section{Recommended Citation}

Gray, Andrew Karl , "Inhibition of Monocyte Chemotaxis and Chemokine Macrophage Inflammatory Protein-1 Alpha, and Interleukin-8 Secretion by Lipopolysaccharide Isolated from Periodontal Pathogens" (2011). Theses and Dissertations (ETD). Paper 98. http://dx.doi.org/10.21007/etd.cghs.2011.0116. 


\title{
Inhibition of Monocyte Chemotaxis and Chemokine Macrophage Inflammatory Protein-1 Alpha, and Interleukin-8 Secretion by Lipopolysaccharide Isolated from Periodontal Pathogens
}

\begin{abstract}
The vast majority of periodontal pathogens are classified as gram negative bacteria. These bacteria have an outermost membrane consisting of lipopolysaccharide (LPS), a molecule that can act as an endotoxin and elicit an immune response. The lipopolysaccharide structure consists of three major regions: oligosaccharide, core, and lipid A. Oligosaccharide is exposed on the cell surface, and lipid A anchors LPS in the outer membrane. LPS has been known to hinder certain defensive mechanisms of the immune system by secreting products that interfere with signals that promote chemotaxis of leukocytes enabling the pathogens to go unrestricted. When LPS binds to the Toll-like receptor it promotes the secretion of proinflammatory cytokines in cells such as the macrophage, monocyte, and endothelial cells. Two such cytokines stimulated by LPS are macrophage inflammatory protein 1-alpha (MIP-1 $\alpha$ ) and interleukin 8 (IL-8) both of which have been characterized as potent monocyte chemoattractants. IL-8 has potency as a chemotactic agent equal to that of $\mathrm{C} 5 \mathrm{a}$. It is a pro-inflammatory mediator of gingivitis and a mediator of the inflammatory response, by serving as a chemical signal that attracts neutrophils. MIP- $1 \alpha$ belongs to a large super family of small inducible cytokines. It is able to stimulate the activity of white blood cells in response to infection or inflammation and is a major factor produced by macrophages stimulated with bacterial endotoxins. The present study examined the interaction of LPS prepared from periodontal pathogens with monocytes, to stimulate them to secrete MIP- $1 \alpha$ and IL-8. The hypothesis of this study is that LPS molecules of more pathogenic periodontal pathogens suppress the secretion of both MIP- $1 \alpha$ and IL-8, in such a way that they can escape detection by the defensive cells, thus facilitating their ability to colonize the oral cavity and may contribute to their pathogenicity.

The LPS from three different periodontal pathogens, Porphyromonas gingivalis, Prevotella denticola, and Fusobacterium nucleatum were isolated under identical conditions. Cultured human monocytic cells were incubated with different concentrations of LPS and then the secretion of MIP- $1 \alpha$ and IL- 8 was measured by enzyme-linked immunosorbent assay (ELISA).

The results demonstrated that LPS of different periodontal pathogens differ in their ability to stimulate inflammatory cytokines. LPS of $P$. gingivalisand $P$. denticola were found to suppress the secretion of both IL- 8 and MIP- $1 \alpha$ at higher concentrations. On the other hand, LPS of $F$. nucleatumstimulated the secretion of IL- 8 and MIP- $1 \alpha$, by monocytes in a dose dependent manner.

The long term objective is to understand the mechanisms by which the periodontal pathogens escape detection by interfering with host defensive functions, such as chemotaxis. This study presents a possible mechanism of chemotaxis interference by LPS from periodontal pathogens by inhibiting the secretion of both MIP- $1 \alpha$ and IL-8. With an understanding of the mechanism by which LPS molecules interfere with chemotaxis, it may be possible to intervene and prevent the tissue destruction associated with periodontal pathogens.
\end{abstract}

\section{Document Type}

Thesis

\section{Degree Name}

Master of Dental Science (MDS) 


\section{Program}

Periodontics

\section{Research Advisor}

Jegdish P. Babu, Ph.D.

\section{Keywords}

Chemokine, Dentistry, IL-8, LPS, MIP, Periodontal

\section{Subject Categories}

Dentistry | Medicine and Health Sciences | Periodontics and Periodontology 
INHIBITION OF MONOCYTE CHEMOTAXIS AND CHEMOKINE

MACROPHAGE INFLAMMATORY PROTEIN-1 ALPHA, AND

INTERLEUKIN-8 SECRETION BY LIPOPOLYSACCHARIDE ISOLATED FROM PERIODONTAL PATHOGENS

\author{
A Thesis \\ Presented for \\ The Graduate Studies Council \\ The University of Tennessee \\ Health Science Center
}

\begin{abstract}
In Partial Fulfillment
Of the Requirements for the Degree

Master of Dental Science

From The University of Tennessee
\end{abstract}

By

Andrew Karl Gray, PharmD., D.D.S.

May 2011 
Copyright (C) 2011 by Andrew K. Gray. All rights reserved. 


\section{DEDICATION}

I dedicate this thesis to my wife Jacynth S. Gray, the love of my life, and to my children Jonathan, Joshua, and Annya Gray for their love and support. 


\section{ACKNOWLEDGEMENTS}

I would like to express my sincere appreciation and thanks to Dr. Jegdish Babu for being my research mentor throughout this master's thesis project and for allowing me to be part of his ongoing studies. I can't thank him enough for his patience, understanding, and wonderful sense of humor throughout this research project.

I would like to thank my Committee members Drs. Peter Di Fiore, Sidney Stein, Edwin L. Thomas, and David A. Tipton for their valuable support and suggestions.

I would like to thank The University of Tennessee Health Science Center, College of Dentistry Alumni Endowment Fund for its financial support of this project. 


\begin{abstract}
The vast majority of periodontal pathogens are classified as gram negative bacteria. These bacteria have an outermost membrane consisting of lipopolysaccharide (LPS), a molecule that can act as an endotoxin and elicit an immune response. The lipopolysaccharide structure consists of three major regions: oligosaccharide, core, and lipid A. Oligosaccharide is exposed on the cell surface, and lipid A anchors LPS in the outer membrane. LPS has been known to hinder certain defensive mechanisms of the immune system by secreting products that interfere with signals that promote chemotaxis of leukocytes enabling the pathogens to go unrestricted. When LPS binds to the Toll-like receptor it promotes the secretion of proinflammatory cytokines in cells such as the macrophage, monocyte, and endothelial cells. Two such cytokines stimulated by LPS are macrophage inflammatory protein 1-alpha (MIP-1 $\alpha$ ) and interleukin 8 (IL-8) both of which have been characterized as potent monocyte chemoattractants. IL-8 has potency as a chemotactic agent equal to that of $\mathrm{C} 5 \mathrm{a}$. It is a pro-inflammatory mediator of gingivitis and a mediator of the inflammatory response, by serving as a chemical signal that attracts neutrophils. MIP-1 $\alpha$ belongs to a large super family of small inducible cytokines. It is able to stimulate the activity of white blood cells in response to infection or inflammation and is a major factor produced by macrophages stimulated with bacterial endotoxins. The present study examined the interaction of LPS prepared from periodontal pathogens with monocytes, to stimulate them to secrete MIP-1 $\alpha$ and IL-8. The hypothesis of this study is that LPS molecules of more pathogenic periodontal pathogens suppress the secretion of both MIP-1 $\alpha$ and IL-8, in such a way that they can escape detection by the defensive cells, thus facilitating their ability to colonize the oral cavity and may contribute to their pathogenicity.
\end{abstract}

The LPS from three different periodontal pathogens, Porphyromonas gingivalis, Prevotella denticola, and Fusobacterium nucleatum were isolated under identical conditions. Cultured human monocytic cells were incubated with different concentrations of LPS and then the secretion of MIP-1 $\alpha$ and IL-8 was measured by enzyme-linked immunosorbent assay (ELISA).

The results demonstrated that LPS of different periodontal pathogens differ in their ability to stimulate inflammatory cytokines. LPS of $P$. gingivalis and $P$. denticola were found to suppress the secretion of both IL- 8 and MIP- $1 \alpha$ at higher concentrations. On the other hand, LPS of F. nucleatum stimulated the secretion of IL-8 and MIP-1 $\alpha$, by monocytes in a dose dependent manner.

The long term objective is to understand the mechanisms by which the periodontal pathogens escape detection by interfering with host defensive functions, such as chemotaxis. This study presents a possible mechanism of chemotaxis interference by LPS from periodontal pathogens by inhibiting the secretion of both MIP-1 $\alpha$ and IL-8. With an understanding of the mechanism by which LPS molecules interfere with chemotaxis, it may be possible to intervene and prevent the tissue destruction associated with periodontal pathogens. 


\section{TABLE OF CONTENTS}

CHAPTER 1. INTRODUCTION AND LITERATURE REVIEW .............................1

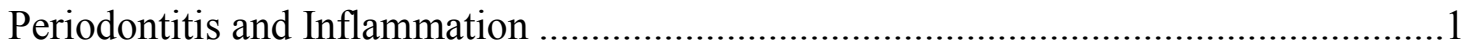

Pathogens Associated with Periodontal Disease .........................................................2

Lipopolysaccharide and Gram-Negative Bacteria .....................................................

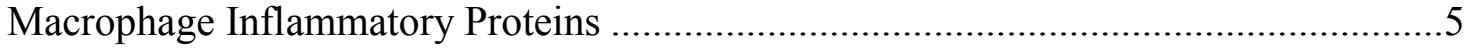

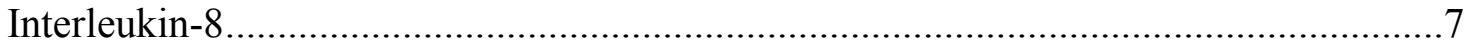

CHAPTER 2. SPECIFIC OBJECTIVES ............................................................8

Specific Aim 1: Isolation and Purification of LPS and Lipid A .................................

Specific Aim 2: Cytokine Expression of Il-8 .......................................................

Specific Aim 3: Cytokine Expression of MIP-1 1 ..............................................

CHAPTER 3. MATERIALS AND METHODOLOGY .............................................9

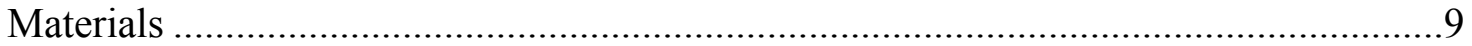

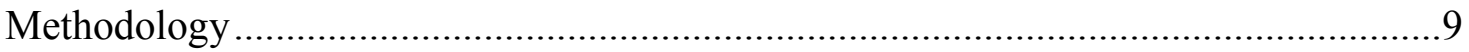

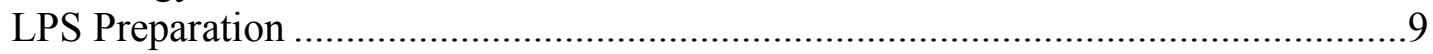

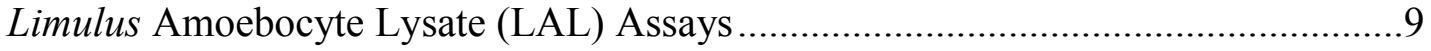

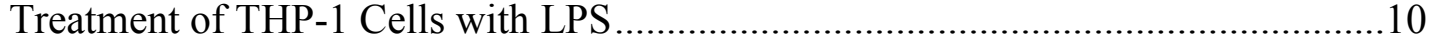

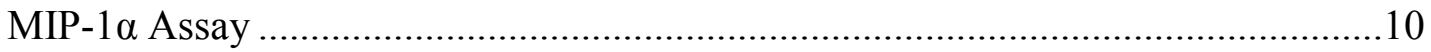

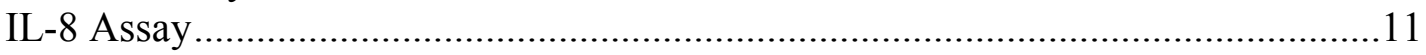

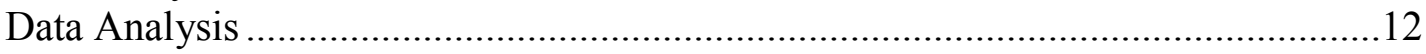

CHAPTER 4. RESULTS ..............................................................................13

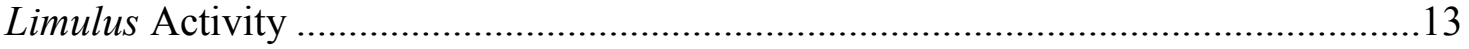

Influence of Periodontal Pathogens' LPS on MIP-1 $\alpha$ Secretion by Monocytes ...........13

Influence of Periodontal Pathogens on Monocytes to Secrete IL-8 ...........................22

IL-8 Secretion by THP-1 Cells in Response to LPS of Periodontal Pathogens ............25

Effect of Periodontal Pathogens LPS Combinations on Monocytes to Secrete IL-8 ....31

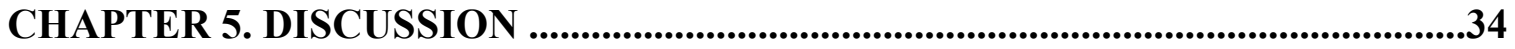

The Secretion of MIP-1 $\alpha$ by THP-1 Cells in Response to LPS of Periodontal

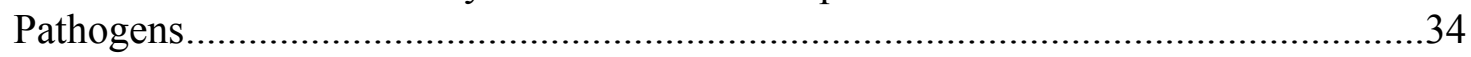

The Secretion of IL-8 by THP-1 Cells in Response to LPS of Periodontal

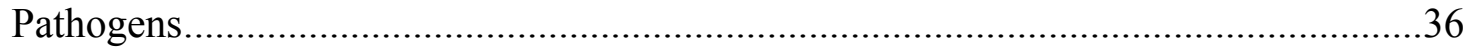

The Secretion of IL-8 and MIP-1 $\alpha$ in the Presence of F. nucleatum LPS ...................37

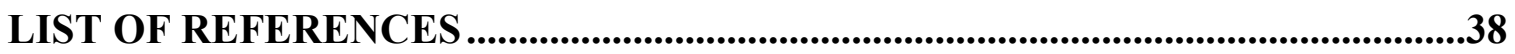

VITA 


\section{LIST OF FIGURES}

Figure 1-1. Diagram Representing the Structure of Lipopolysaccharide

Figure 4-1. Endotoxin Activity of LPS Preparations from E. coli and Oral Pathogens at $10 \mathrm{ng} / \mathrm{ml}$

Figure 4-2. Demonstration of Effect of Porphyromonas gingivalis LPS

Concentration on MIP-1 $\alpha$ Secretion .15

Figure 4-3. Demonstration of Effect of Prevotella denticola LPS Concentration on MIP-1 $\alpha$ Secretion

Figure 4-4. Demonstration of Effect of Fusobacterium nucleatum LPS

Concentration on MIP-1 $\alpha$ Secretion.

Figure 4-5. Demonstration of Effect of E. coli LPS Concentration on MIP- $1 \alpha$ Secretion.

Figure 4-6. Demonstration of Effect of Periodontal Pathogen LPS Concentration on MIP-1 $\alpha$ Secretion. .20

Figure 4-7. Demonstration of Effect of Fusobacterium nucleatum LPS Combined with Prevotella denticola LPS on MIP-1 $\alpha$

Secretion

Figure 4-8. Demonstration of Effect of Fusobacterium nucleatum LPS

Combined with Porphyromonas gingivalis LPS on MIP-1 $\alpha$

Secretion.

Figure 4-9. Demonstration of Effect of Fusobacterium nucleatum LPS

Combined with Porphyromonas gingivalis LPS at Timed

Interval on MIP- $1 \alpha$ Secretion .24

Figure 4-10. Demonstration of Effect of Porphyromonas gingivalis LPS

Concentration on IL-8 Secretion

Figure 4-11. Demonstration of Effect of Prevotella denticola LPS Concentration on IL-8 Secretion.

Figure 4-12. Demonstration of Effect of Fusobacterium nucleatum LPS Concentration on IL-8 Secretion .28

Figure 4-13. Demonstration of Effect of E. coli LPS Concentration on IL-8

Secretion 
Figure 4-14. Demonstration of Effect of Periodontal Pathogen LPS Concentration

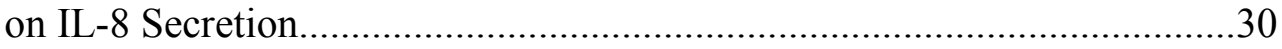

Figure 4-15. Demonstration of Effect of Fusobacterium nucleatum LPS in Combination with Porphyromonas gingivalis LPS or Prevotella denticola LPS Concentrations on IL-8 Secretion.

Figure 4-16. Demonstration of Effect of Fusobacterium nucleatum LPS Combined with Porphyromonas gingivalis LPS at Timed Interval on IL-8 Secretion 


\section{LIST OF ABBREVIATIONS}

\begin{tabular}{|c|c|}
\hline$\mu \mathrm{g} / \mathrm{ml}$ & Microgram per Milliliter \\
\hline$\mu 1$ & Microliter \\
\hline$\mu \mathrm{M}$ & Micromolar \\
\hline$A a$ & Aggregatibacter actinomycetemcomitans \\
\hline ATCC & American Type Culture Collection \\
\hline BSA & Bovine Serum Albumin \\
\hline $\mathrm{CO}_{2}$ & Carbon Dioxide \\
\hline E. coli $(E c)$ & Escherichia coli \\
\hline ELISA & Enzyme-Linked Immunosorbent Assay \\
\hline F. nucleatum (Fn) & Fusobacterium nucleatum \\
\hline GCF & Gingival Crevicular Fluid \\
\hline ICAM & Inter-Cellular Adhesion Molecule \\
\hline $\operatorname{IgG}$ & Immunoglobulin $\mathrm{G}$ \\
\hline IL-1 $\alpha$ & Interleukin-1-Alpha \\
\hline IL-1 $\beta$ & Interleukin-1-Beta \\
\hline IL-8 & Interleukin-8 \\
\hline $\mathrm{kDa}$ & Kilodalton \\
\hline $\mathrm{KDO}$ & Keto-Deoxyoctulosonate \\
\hline LAL & Limulus Amebocyte Lysate \\
\hline LBP & Lipopolysaccharide-Binding Protein \\
\hline LPS & Lipopolysaccharide \\
\hline M & Molar \\
\hline
\end{tabular}




\begin{tabular}{|c|c|}
\hline MIP-1 $1 \alpha$ & Macrophage Inflammatory Protein-1 Alpha \\
\hline MMP & Matrix Metalloproteinases \\
\hline $\mathrm{N}$ & Number \\
\hline $\mathrm{ng} / \mathrm{ml}$ & Nanogram per Milliliter \\
\hline $\mathrm{nm}$ & Nanometer \\
\hline PBS & Phosphate Buffered Saline \\
\hline P. denticola $(P d)$ & Prevotella denticola \\
\hline$P$. gingivalis $(P g)$ & Porphyromonas gingivalis \\
\hline $\mathrm{pg} / \mathrm{ml}$ & Picograms per Milliliter \\
\hline$P i$ & Prevotella intermedia \\
\hline PMN & Polymorphonuclear Leukocyte \\
\hline RPMI & Roswell Park Memorial Institute \\
\hline$T f$ & Tannerella forsythia \\
\hline THP-1 & Human Acute Monocytic Leukemia Cell Line \\
\hline TLR & Toll-Like Receptor \\
\hline $\mathrm{TNF} \alpha$ & Tumor Necrosis Factor-Alpha \\
\hline
\end{tabular}




\section{CHAPTER 1. INTRODUCTION AND LITERATURE REVIEW}

\section{Periodontitis and Inflammation}

Periodontal disease is an infection of the attachment apparatus leading to the destruction of the alveolar process and connective tissue that support the tooth, with the end sequelae being tooth loss. Periodontal disease is initiated by plaque which is composed of numerous types of bacteria that produce toxins which in turn stimulate a chronic inflammatory response in which the body in essence turns on itself, destroying the tissues and bone that support the teeth. ${ }^{1}$ Studies have been performed to evaluate the composition of the subgingival biofilm and identified key periodontal pathogens by both cultivation and molecular methods. More than 700 different species have been identified in the oral cavity, many of which are yet to be cultivated. ${ }^{2}$

According to the National Institute of Dental Research, periodontal disease is one of the most common human diseases. It has been estimated that around $80 \%$ of all adults are affected with at least one site having clinical attachment loss of greater than two millimeters (mm). ${ }^{3}$ This number increases to around $90 \%$ for those aged 55 to 64 having at least one site with greater than $2 \mathrm{~mm}$ of clinical attachment loss. ${ }^{4}$ The incidence of periodontal disease is increasing in parallel with the ability of the adult population to retain their dentition for longer time periods. Despite the continued efforts of dental professionals to treat this disease by both surgical and non-surgical methods, prevention of the disease appears to be at times impossible. The inability to prevent disease has been recognized to be due to the complications inherent in the role of bacterial modulation of the immune system. Recently more and more literature has been published that demonstrate an association between a variety of systemic diseases and periodontal disease. Loe et al., has described periodontal disease as the sixth complication of diabetes. ${ }^{5}$ While other studies have demonstrated diseases such as diabetes, heart disease, respiratory diseases, Alzheimer's and osteoporosis are associated with periodontal disease. $^{6}$

Inflammation has been found to be a causative factor of both periodontal disease and various systemic diseases in a susceptible host. There is both a local inflammatory response in the periodontium and a systemic inflammatory response throughout the body in people who also suffer from one of the diseases linked to periodontal disease. This is significant because treating the individual's periodontal disease reduces overall inflammation, which may help alleviate some of their symptoms from other diseases. Likewise, lowering the total body inflammation may help quell some of the periodontal symptoms and inflammation. However, the mechanisms associated with these inflammatory diseases are poorly understood. Interaction of bacterial products and antigens of periodontal pathogens elicits a host response which engages inflammatory cells resulting in the release of cytokines. Some recent studies suggest the up-regulation of proinflammatory cytokines such as tumor necrosis factor-alpha (TNF $\alpha)$ and interleukin-1beta (IL-1 $\beta$ ). These are primarily products of innate immune cells such as macrophages and neutrophils. In addition they play a key role in the chronic 
inflammatory lesion. ${ }^{7}$ These cytokines stimulate and activate resident fibroblasts in the periodontal tissues to produce matrix metalloproteinase (MMP) and other proteases, which degrade the surrounding connective tissue. These cytokines have been shown to be potent stimulators of local osteoclastogenesis, which leads to efficient degradation of periodontal tissues. ${ }^{7}$ Periodontitis may involve both the direct cytotoxic and proteolytic effects of oral microorganisms and the indirect pathologic consequences of the host immune response to these microorganisms. ${ }^{8}$ Aggregatibacter actinomycetemcomitans (Aa), Porphyromonas gingivalis (P. gingivalis), and Tannerella forsythia (Tf) have been implicated as principal anaerobic gram-negative bacteria in adult periodontitis. ${ }^{8}$ A wide variety of virulence factors, including lipopolysaccharide (LPS), fimbriae, haemagglutinin, leukotoxin, cytolethal distending toxin, and haemolysins have contributed to the pathogenicity of these organisms. ${ }^{9}$

\section{Pathogens Associated with Periodontal Disease}

The change from periodontal health to disease is often associated with the displacement of a predominantly gram-positive bacterial flora in the gingival crevice by gram-negative anaerobes. A small number of gram-negative species have been consistently associated with specific forms of periodontal disease among these are $P$. gingivalis, Tf, and Fusobacterium nucleatum. ${ }^{8}$ These organisms are implicated in the damage of tissue through virulence factors such as fimbriae, capsule, and endotoxin and through deregulation of the host's innate and acquired immunity systems. ${ }^{9}$ Slots et al., studied adults with advanced chronic periodontitis and reported $A a$ in $50 \%$ of progressing lesions but in only $6 \%$ of non-progressing lesions. $P$. gingivalis was seen in $42 \%$ to $52 \%$ of progressing lesions and was seen in 14\% of non-progressing sites. Prevotella intermedia was found in $59 \%$ to $89 \%$ of progressing lesions and from $36 \%$ to $53 \%$ of non-progressing sites. ${ }^{10} P$. gingivalis is categorized as part of the red complex bacterium as it is associated with the more severe forms of periodontitis. In addition, it is grouped with the black pigmented bacteria due to its ability to accumulate hemin which serves the purpose of providing an iron source for growth. The organism appears to lack the ability to secrete known iron chelating compounds and must use alternate mechanisms to sequester and transport exogenous iron. $P$. gingivalis possesses an armamentarium of cell surface-associated and extracellular activities, which are studied for their virulence potential. Ginigipains is an example of one such virulence factor secreted by $P$. gingivalis, work to degrade cytokines and down regulate the host response. Other virulence factors are putative adhesins which interact with other bacteria, epithelial cells, and extracellular matrix proteins. The virulence factors can be secreted or cell-bound enzymes, toxins, or haemolysins and have been shown to play a significant role in the spread of the microorganisms through tissue, in tissue destruction, and in evasion of host defenses. ${ }^{11}$

The lipopolysaccharide of $P$. gingivalis is not inhibited in human serum and can induce production of IL- $1 \alpha$ by macrophages and monocytes. In addition, $P$. gingivalis has a hydrocarbon structure with high antigenic and immunogenic potency that triggers an IgG response. ${ }^{11}$ This decreases the effectiveness of the complement pathway of the 
immune system. ${ }^{12}$ Furthermore it was demonstrated by Cutler et al. that the opsonization and clearance of $P$. gingivalis by neutrophils required the response of specific IgG-type antibodies. ${ }^{13}$ Antibodies which neutralize $P$. gingivalis enzymes are essential to ensure the normal phagocytic activity of neutrophils when the alternative complement pathway is ineffective. Hence, these antibodies do not function as opsonins but rather serve to neutralize toxic bacterial products, such as proteases.

Although not as prevalent as $P$. gingivalis, Prevotella species are a major portion of the microflora of human gingival crevices in patients with periodontal disease. ${ }^{14}$ The similarity of the phenotypic characteristics of these species often makes their routine differentiation and identification difficult. ${ }^{14} P$. intermedia is one of the organisms of the Prevotella species associated with periodontal disease. Current evidence indicates that the prevalence of subgingival species such as putative periodontal pathogens (being more evident in the orange and red complexes) varies between geographical locations and ethnic groups. ${ }^{9}$ In a study carried out by Maestre et al., the isolation rate of anaerobic periodontal pathogens in patients with periodontitis was $60 \%$ Prevotella buccae, $40 \%$ Prevotella denticola, $38 \% \mathrm{~F}$. nucleatum, $35 \%$ P. intermedia and $23 \%$ Veillonella. ${ }^{15} P$. intermedia colonizes early in the infection process, and like other oral bacteria it can bind and co-aggregate with other bacteria, and can adhere to epithelial cells. It has the added benefit in that it carries antibiotic resistant genes, and may be responsible for antibiotic resistance in disease progression. It has tissue degradation properties which are derived from proteases and haemolysin.

F. nucleatum is an anaerobe, with a high capacity to adapt to and reduce an oxygenated environment. It is commonly isolated from human subgingival plaques associated with both healthy and periodontally diseased sites. ${ }^{16}$ The organisms have been found in subgingival sites associated with long-standing gingivitis, in association with spirochetes in lesions of acute necrotizing ulcerative gingivitis, and in periodontitis. ${ }^{16,17}$ $F$. nucleatum is also regarded as a key organism for dental plaque maturation due to its extensive co-aggregating capacity. ${ }^{18}$ Bradshaw et al., have suggested that $F$. nucleatum could be a bridge or mediator of co-aggregation between facultative and obligate anaerobic species. They proposed that this co-aggregation was the mechanism by which strict anaerobes, such as $P$. gingivalis, survive under aerobic conditions, due to the formation of microenvironments in which facultative organisms reduce oxygen tension. ${ }^{19}$

The host response is of equal importance to bacteria in the etiology of periodontal disease. The host response to periodontal pathogens involves numerous aspects of the immune system. Individual susceptibility to periodontal pathogens is of great importance in determining the onset and extent of periodontitis. Therefore it is necessary to understand the factors that influence susceptibility to periodontitis, which include environmental risk factors and genetic variance. In addition, it is also important to understand the mechanisms by which the immune system operates to protect an individual from injury as a result of colonization by pathogenic bacteria. The complement system is part of the innate immune system and functions to aid the ability of antibodies and phagocytic cells to clear pathogens from the host. This system can be activated by either the classical or alternative pathway. In the alternative complement pathway a 
specific antibody is not needed for the commencement of an immune response, and therefore activation takes place much faster. The caveat of this faster activation is that only specific types of antigens can activate this pathway; one such molecule is LPS. The classical complement pathway detects antibody-antigen complexes and eventually results in bacterial opsonization. Activation of the complement system is one of the earliest host immune responses in the gingival crevicular space. The presence of bacteria in the gingival pocket can activate this system by either the classical or alternative pathway. ${ }^{20}$ The recruitment of neutrophils is another mechanism the body uses in the defense against periodontal pathogens. Neutrophil infiltration is the first line of defense against periodontal pathogens, and the associated inflammatory cell infiltrate in gingival tissue and GCF is predominantly formed by neutrophils. ${ }^{21}$ When neutrophils become ineffective, the second line of defense is the recruitment of monocytes which function as phagocytic cells. It has been postulated that neutrophils follow the concentration gradient of interleukin 8 (IL-8) and move from cell to cell via the inter-cellular adhesion molecule (ICAM) receptor. ${ }^{22}$ In the gingival pocket, active neutrophils attempt microbial elimination by phagocytosis. However, some of the periodontal pathogens are able to evade the neutrophils, leading to an over production of phagocytes in the gingival crevice which in turn gives rise to degranulation due to ineffective phagocytosis. ${ }^{23}$ Degranulation of the polymorphonuclear leukocyte $(\mathrm{PMN})$ is accompanied by the release of endogenous proteases that, alongside the bacterial proteases, produce degradation of the cell matrix causing continuous destruction of the periodontal tissue. ${ }^{23}$

\section{Lipopolysaccharide and Gram-Negative Bacteria}

Lipopolysaccharide is a molecule in which lipids and polysaccharides are linked via covalent bonds. The molecule acts as an endotoxin and is located on the outer membrane of gram-negative bacteria where it can elicit a strong immune response in animals. ${ }^{24}$ LPS is an extremely potent toxin stimulating macrophage activation at concentrations of LPS as low as $1 \mathrm{pg} / \mathrm{mL}$. Three major receptors expressed on the surface of monocytes and macrophages are known to bind to LPS. These include CD14, the macrophage scavenger receptor, and the $\beta 2$ leukocyte integrins. ${ }^{25}$ The CD14 receptor is capable of initiating signals to a cell, resulting in phagocyte activation, bacterial internalization, and the activation of bactericidal defenses.

When LPS binds to the CD14 receptor, it promotes the secretion of proinflammatory cytokines in cells such as the macrophage. ${ }^{24}$ The periodontal pathogens such as $P$. gingivalis secrete LPS, initiating a cascade of events leading to the release of various inflammatory mediators. Once secreted, LPS may then enter the plasma. Upon entrance of LPS into the plasma it is then either inactivated by one of the plasma proteins or it binds the LPS-binding protein (LBP). ${ }^{25}$ LBP is an acute phase reactant, synthesized by hepatocytes, which catalyses LPS transfer to its receptor, membrane CD14 present in monocytes /macrophages or soluble CD14 (sCD14). ${ }^{26}$ When LPS binds to the protein carrier LBP, it allows binding to CD14 receptors on activated monocytes, which results in attachment to the cell wall and begins cellular activation. In the presence of LBP, the sensitivity of monocytes to LPS may be as high as 100 to 1000 fold. ${ }^{26}$ LPS secreted by $P$. 
gingivalis is thought to interact with receptors such as Toll-like receptors (TLR). If LPS is bound to TLR-2 it activates epithelial cells and if bound to TLR-4 it activates endothelial cells. Both of which when stimulated by $P$. gingivalis LPS produces proinflammatory cytokines. ${ }^{27}$ The type of cytokine produced is thought to be dependent upon the LPS structure, via Lipid A moieties that contribute to induce different cellular effects. $^{28,29}$ An alternate hypothesis is that the type of cytokine produced is due to lipoproteic contaminants of LPS. ${ }^{30}$

It has been demonstrated that individuals with periodontal disease have greater CD14 levels as compared to healthy individuals. ${ }^{31}$ It has also been demonstrated that there are increases in serum level of LBP and antibodies against LPS of periodontal pathogens in patients with periodontitis. ${ }^{32}$

LPS has a unique structure (Figure 1-1) comprised of 3 major parts: $O$ antigen, core oligosaccharide, and lipid A. ${ }^{33}$ The O-antigen (also known as the O-polysaccharide) is a repeating glycan polymer attached to the core oligosaccharide, and comprises the outermost domain of the LPS molecule. It is this portion of the LPS that provides most of the structural heterogeneity of the molecule. ${ }^{34}$ If the $\mathrm{O}$ antigen is absent from bacterial LPS the molecule would be referred to as rough, due to the colonial morphology, where as the presence of the $\mathrm{O}$ chains would render the molecule smooth. ${ }^{34}$

The structure of the $\mathrm{O}$ polysaccharide defines the $\mathrm{O}$-antigen serological specificity of an organism, but the numbers of unique $\mathrm{O}$ antigens within a species vary considerably. ${ }^{35}$ Understanding LPS structural variation in bacterial pathogens is important because the composition or size of the $\mathrm{O}$-antigen might be a reliable indicator of virulence potential. ${ }^{36}$ In general, the primary role(s) of the $\mathrm{O}$ antigen appears to be protective and may contribute to bacterial evasion of host immune responses, particularly the alternative complement cascade. ${ }^{33}$ The core oligosaccharide is a small chain of sugars such as hexose and keto-deoxyoctulosonate (KDO). This portion of the LPS molecule is extremely diverse among bacterial species and even within strains of species. It can be divided into two portions: an inner core and an outer core. The inner core consists of 10 to 12 sugars and KDO. It is bound to lipid A via a ketosidic bond, which is susceptible to acid cleavage. Therefore a weak acid may be used to separate the lipid and polysaccharide portions of LPS.

\section{Macrophage Inflammatory Proteins}

Macrophage inflammatory proteins (MIP) belong to the family of chemotactic cytokines known as chemokines. There are two major forms, MIP-1 $\alpha$ and MIP-1 $\beta$ both of which are produced by macrophages when stimulated with bacterial endotoxins. ${ }^{37}$ The role of MIP- $1 \alpha$ as it relates to periodontal disease remains to be elucidated. It has been shown that MIP-1 $\alpha$ acts to stimulate monocytes and/or osteoclast progenitor cells to become active osteoclasts. ${ }^{38}$ MIP- $1 \alpha$ was found elevated in patients with multiple myeloma months before any radiographic detection of bone loss could be depicted. ${ }^{39}$ MIP-1 $\alpha$ was also shown to be elevated in patients with periapical lesions. ${ }^{40}$ Studies have 


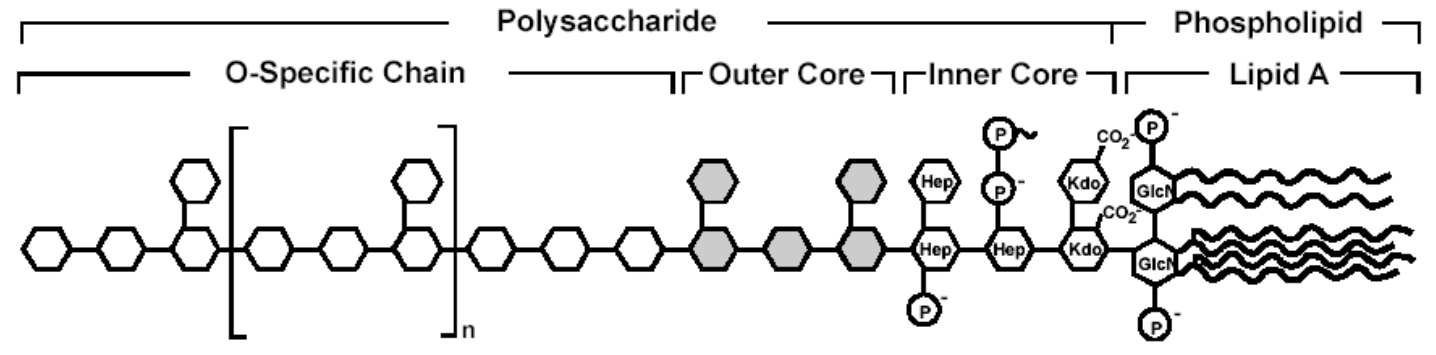

Figure 1-1. Diagram Representing the Structure of Lipopolysaccharide. 
shown MIP- $1 \alpha$ to be elevated in patients with periodontal disease and to be directly correlated with increased probing depths. ${ }^{41}$ It has also been shown that patients with periodontal disease based purely on bone loss had a 50 fold elevation in MIP- $1 \alpha .^{42}$ In addition to periodontal disease and multiple myeloma, MIP- $1 \alpha$ is associated with asthma in which it is induced by LPS and down-regulated by drugs that up-regulate cyclic AMP, such as $\beta$-agonist and phosphodisterase inhibitors. ${ }^{43}$ Ryu et al. recently found MIP- $1 \alpha$ expression in gingival epithelial cells was induced by LPS, and they concluded that MIP$1 \alpha$ expression by gingival epithelial cells may be important in initiating inflammation. ${ }^{44}$ Together these studies indicate that MIP-1 $\alpha$ may play an important role in both the early and later stages of inflammatory related periodontitis.

\section{Interleukin-8}

Interleukin-8 (IL-8) is a chemokine produced by macrophages and epithelial cells. It is a polypeptide with a structure consisting of seventy-two amino acids. This chemokine is one of the major mediators of the inflammatory response and functions as a chemoattractant. ${ }^{45}$ As a chemoattractant IL-8 presents with a profile of activity similar to the classic peptides for chemotaxis, C5a and $\mathrm{N}$-formyl-methionyl-leucyl-phenylalanine. ${ }^{45}$ The primary function of IL-8 is to recruit neutrophils to phagocytize the antigens which trigger antigen pattern Toll-like receptors. Fitzgerald and colleagues suggested that IL-8 may play a crucial role in the recruitment and activation of neutrophils and $\mathrm{T}$ lymphocytes in periodontitis, by demonstrating an elevation of IL-8 in chronically inflamed gingival tissues. ${ }^{46}$ However it has also been demonstrated that IL- 8 was found at greater concentrations adjacent to lower sulcular depths. ${ }^{47}$ Stathopoulou studied the host cytokine response to $P$. gingivalis and concluded that changes in the crevicular cytokine profile have consequences in periodontal disease pathogenesis and may be targeted for the development of diagnostic and therapeutic modalities. ${ }^{48}$ 


\section{CHAPTER 2. SPECIFIC OBJECTIVES}

The objective of this study was to investigate the effect of LPS isolated from three different periodontal pathogens on the secretion of cytokines by cultured monocytes.

This study tested the hypothesis that the LPS of oral pathogens suppress the secretion of IL- 8 by host inflammatory cells thus contributing to interference with neutrophil chemotaxis ability. In addition, the suppression of MIP- $1 \alpha$ secretion may reduce the ability of host defense cells to detect oral pathogens. Together these factors may then aid the pathogenic bacteria to escape detection by the defensive cells, thus facilitating their colonization and pathogenicity.

\section{Specific Aim 1: Isolation and Purification of LPS and Lipid A}

To Isolate the LPS from periodontal pathogens, $F$. nucleatum, $P$. gingivalis, and P. denticola. The endotoxin activity of the isolated LPS will be determined by the Limulus assay.

\section{Specific Aim 2: Cytokine Expression of Il-8}

To study the effect of LPS on cultured monocyte to secrete IL-8, a cytokine known to play a key role in chemotaxis.

\section{Specific Aim 3: Cytokine Expression of MIP-1a}

To investigate the differences in LPS from periodontal pathogens, $F$. nucleatum, $P$. gingivalis, and $P$. denticola, by testing their ability to stimulate or suppress another cytokine, MIP-1 $\alpha$, which has been recognized to be an important chemokine. 


\section{CHAPTER 3. MATERIALS AND METHODOLOGY}

\section{Materials}

The bacteria, $P$. gingivalis (25260), $P$. denticola (33185), and $F$. nucleatum (10953), were obtained from ATCC, Rockville, MD. The bacteria were grown in the laboratory under anaerobic conditions in thioglycollate broth at $37^{\circ} \mathrm{C}$ in an anaerobic jar for 72 hours. The crystal phenol was obtained from Fischer Scientific, Pittsburgh, PA. Limulus amebocyte lysate was purchased from the Associates of Cape Cod, Inc. Fallmouth, MA. THP-1 cells (ATCC TIB202) were obtained from ATCC, Rockville, MD. Stabilized chromogen and peroxide solutions were obtained from R\&D Systems, Minneapolis, MN. Commercial enzyme-linked immunosorbent assay (ELISA) kits from R\&D Systems were employed to measure the cytokines MIP- $1 \alpha$ and IL-8 released by the monocytes. LPS from E. coli was purchased from Sigma-Aldrich, St. Louis, MO.

\section{Methodology}

\section{LPS Preparation}

Periodontal pathogens were grown in liter batches of thioglycollate broth (Difco) for 72 hours in an anaerobic jar. The bacteria were harvested by centrifugation and the cell pellets were washed with physiological saline, then with de-ionized water and centrifuged. The bacterial cell pellets were lyophilized and the LPS was prepared by the hot phenol-water extraction method as described by Westphal and Jann. ${ }^{49}$ Batches of 0.25 $\mathrm{g}$ of the lyophilized bacteria were suspended in $200 \mathrm{ml}$ of $90 \%$ phenol and hot water and incubated at $67^{\circ} \mathrm{C}$ for 15 minutes and then stirred for another 15 minutes on a stirrer at room temperature. The mixture was chilled on ice to $10^{\circ} \mathrm{C}$ to separate the phases. The resultant LPS-containing aqueous phase was then collected from the lower phenol phase. The non-aqueous phenol phase was subjected to a second extraction by adding an additional $200 \mathrm{ml}$ of water. The pooled aqueous phases were dialyzed against distilled water at $4^{\circ} \mathrm{C}$ for 48 hours. The aqueous phase was collected, and frozen, and then lyophilized. The purity and protein contamination of the isolated LPS was confirmed by gel electrophoresis $\left(10 \%\right.$ polyacrylamide gel containing $0.1 \%$ sodium dodecyl sulfate) ${ }^{50}$ LPS samples were sonicated gently prior to electrophoresis, and then the gel was stained with silver nitrate stain.

\section{Limulus Amoebocyte Lysate (LAL) Assays}

The LPS activity of periodontal pathogens was measured with the Limulus amoebocyte assay. ${ }^{51}$ The Limulus endotoxin assay is a test developed from the blood cells of the horseshoe crab that detects minute amounts of endotoxins in fluids. All assays were conducted in 96-well microplate; a computer-controlled Bio-Rad microplate reader 
was used. A turbidimetric assay was used, in which the increasing turbidity caused by the gelation of the Limulus lysate in response to LPS was followed over time. Samples were prepared in a volume of $0.2 \mathrm{ml}$. LPS preparations from $P$. denticola, $F$. nucleatum, and $P$. gingivalis and suspended to concentrations of 0.1 to $100 \mathrm{ng} / \mathrm{ml}$. Highly purified LPS from E. coli $\mathrm{K} 235$ was used to prepare the standards over a concentration range of $0.1 \mathrm{ng} / \mathrm{ml}$ to $100 \mathrm{ng} / \mathrm{ml}$. The assay was initiated by addition of $50 \mu \mathrm{l}$ of Limulus lystate reagent to each well containing appropriate dilutions of LPS. The samples were read at an absorbance of $450 \mathrm{~nm}$. Plots were made of the absorbance of each sample over time, and the curves were compared with those of the E. coli LPS standards. The activity of each LPS sample in causing gelation of Limulus lysate was expressed in units corresponding to the activity of $1 \mathrm{ng} / \mathrm{ml}$ of $E$. coli LPS.

\section{Treatment of THP-1 Cells with LPS}

THP-1 are mature cells in the monocyte/macrophage lineage with a normal diploid karyotype, and they produce several cytokines in response to purified endotoxin. These non-adherent cells were maintained in continuous culture with RPMI 1640 (GIBCO/BRL, Grand Island, NY), 10\% fetal bovine serum (GIBCO/BRL), and $0.05 \mathrm{mM}$ 2-mercaptoethanol $(\mathrm{GIBCO} / \mathrm{BRL})$ in an atmosphere of $5 \% \mathrm{CO}_{2}$ at $378^{\circ} \mathrm{C}$. The doubling time for these cells under these conditions is approximately $48 \mathrm{~h}$. THP-1 cells were treated with phorbol 12-myristate 13 -acetate $\left(10^{-7} \mathrm{M}\right.$; Calbiochem Co., La Jolla, Calif.) to induce maturation of the monocytes and became macrophage-like; differentiated macrophages were identified by morphological features and their ability to adhere to plastic. Before experimentation or treatment with phorbol-12-myristate-13-acetate, THP1 cells were washed three times with culture medium without fetal bovine serum and resuspended to a concentration of $1 \times 10^{6}$ cells per ml. Cell viability was determined to be $95 \%$ by the trypan blue dye exclusion assay. Different concentrations of bacterial LPS (1, 5,10 , and $20 \mathrm{ng} / \mathrm{ml}$ ) were added and incubated for 72 hours. Supernatant fluids were collected, centrifuged and assayed for the secreted cytokines, MIP-1 $\alpha$ and IL- 8 by ELISA. Variations of this experiment were carried out with combinations of bacterial LPS. Concentrations of $10 \mathrm{ng} / \mathrm{ml}$ of LPS from different periodontal pathogens were added together. The LPS of one pathogen was first added to the monocytes and then at varying intervals (baseline, 15 minutes, 30 minutes, and 60 minutes) the LPS of the second pathogen was added and the incubation ran for 72 hours. Supernatant fluids were collected, centrifuged and assayed for the secreted cytokines, MIP-1 $\alpha$ and IL- 8 by ELISA.

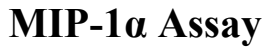

THP-1 cells were prepared as described above. ELISA kits were employed to measure the concentration of MIP-1 $\alpha$ released from the THP-1 cells when stimulated with LPS of $P$. gingivalis, $P$. denticola, $F$. nucleatum and $E$. coli LPS. The standard for the MIP- $1 \alpha$ assays was reconstituted to a concentration of $90 \mathrm{ng} / \mathrm{ml}$ with $0.5 \mathrm{ml}$ of reagent

diluent consisting of $1 \%$ bovine serum albumin (BSA) in phosphate buffered saline 
(PBS), $\mathrm{pH}$ 7.2-7.4. Upon reconstitution of the standard a stock solution was prepared in a tube to produce the standard with a concentration of $500 \mathrm{pg} / \mathrm{ml}$. The stock solution was stored at $2-8^{\circ} \mathrm{C}$ for no longer than 60 days. A seven point standard curve using 2 fold serial dilutions with $1 \% \mathrm{BSA}$ in PBS, and a high standard of $500 \mathrm{pg} / \mathrm{ml}$ was utilized. The assay dilution series was produced with the following concentrations: $500 \mathrm{pg} / \mathrm{ml}$, $250 \mathrm{pg} / \mathrm{ml}, 125 \mathrm{pg} / \mathrm{ml}, 62.5 \mathrm{pg} / \mathrm{ml}, 31.25 \mathrm{pg} / \mathrm{ml}, 15.625 \mathrm{pg} / \mathrm{ml}, 7.8125 \mathrm{pg} / \mathrm{ml}$ and 3.9 $\mathrm{pg} / \mathrm{ml}$. The reagent diluent served as the zero standard. The microplates were coated with a mouse monoclonal antibody against human MIP-1 $\alpha$. The concentrations of LPS tested for the periodontal pathogens were $1 \mathrm{ng} / \mathrm{ml}, 5 \mathrm{ng} / \mathrm{ml}, 10 \mathrm{ng} / \mathrm{ml}$, and $20 \mathrm{ng} / \mathrm{ml}$. The standard, samples and control were incubated at room temperature for 2 hours. Following incubation, each well was aspirated and washed 4 times with wash buffer; the wash buffer consisted of $0.05 \%$ Tween 20 in PBS. An aliquot (100 $\mu 1)$ of biotinylated goat anti-human MIP-1 $\alpha$ serving as the detection antibody at a concentration of $36 \mu \mathrm{g} / \mathrm{ml}$ was added to each well followed by a 2 hour incubation at room temperature. Following incubation, each well was aspirated and washed 4 times with wash buffer. A $100 \mu 1$ working dilution of streptavidin conjugated to horseradish peroxidase was added to each well and incubated at room temperature for 20 minutes. The aspiration and wash step was repeated, and then $100 \mu \mathrm{l}$ of substrate solution, consisting of a 1:1 mixture of stabilized peroxide solution and chromagen solution was added to each well and incubated at room temperature for 20 minutes. To stop the reaction, $50 \mu \mathrm{l}$ of stop solution $\left(2 \mathrm{~N} \mathrm{H}_{2} \mathrm{SO}_{4}\right)$ was added to each well and the microplates were read at $450 \mathrm{~nm}$ absorbance.

\section{IL-8 Assay}

THP-1 cells were prepared as described previously. ELISA kits were employed to measure the concentration of IL-8 released from the THP-1 cells when stimulated with LPS of $P$. gingivalis, $P$. denticola $F$. nucleatum and $E$. coli. The standard for the IL-8 assay was reconstituted to a concentration of $1100 \mathrm{ng} / \mathrm{ml}$ with $0.5 \mathrm{ml}$ of distilled water. Upon reconstitution of the standard a stock solution was prepared in a tube to produce the standard with a concentration of $2000 \mathrm{pg} / \mathrm{ml}$. The stock solution was stored at $2-8^{\circ} \mathrm{C}$ for no longer than 60 days. A seven point standard curve using 2 fold serial dilutions with $0.1 \%$ BSA, $0.05 \%$ Tween 20 in PBS, and a high standard of $2000 \mathrm{pg} / \mathrm{ml}$ was utilized. The assay dilution series was produced with the following concentrations: $2000 \mathrm{pg} / \mathrm{ml}$, $1000 \mathrm{pg} / \mathrm{ml}, 500 \mathrm{pg} / \mathrm{ml}, 250 \mathrm{pg} / \mathrm{ml}, 125 \mathrm{pg} / \mathrm{ml}, 62.5 \mathrm{pg} / \mathrm{ml}, 31.25 \mathrm{pg} / \mathrm{ml}$, and $15.625 \mathrm{pg} / \mathrm{ml}$. The reagent diluent served as the zero standard. The microplates were coated with a mouse monoclonal antibody against human IL-8. The concentrations of LPS tested for the periodontal pathogens were $1 \mathrm{ng} / \mathrm{ml}, 5 \mathrm{ng} / \mathrm{ml}, 10 \mathrm{ng} / \mathrm{ml}$, and $20 \mathrm{ng} / \mathrm{ml}$. The standard, samples and control were incubated at room temperature for 2 hours. Following incubation, each well was aspirated and washed 4 times with wash buffer; consisting of $0.05 \%$ Tween 20 in PBS. An aliquot (100 $\mu 1)$ of biotinylated goat antihuman IL-8 serving as the detection antibody at a concentration of $3.6 \mu \mathrm{g} / \mathrm{ml}$ was added to each well followed by a 2 hour incubation at room temperature. Following incubation, each well was aspirated and washed 4 times with wash buffer. A $100 \mu 1$ working dilution of streptavidin conjugated to horseradish peroxidase was added to each well and incubated at room temperature for 20 minutes. The aspiration and wash step was repeated 
then $100 \mu \mathrm{l}$ of substrate solution, consisting of a 1:1 mixture of stabilized peroxide solution and chromagen solution was added to each well and incubated at room temperature for 20 minutes. To stop the reaction, $50 \mu \mathrm{l}$ of stop solution $\left(2 \mathrm{~N} \mathrm{H}_{2} \mathrm{SO}_{4}\right)$ was added to each well and the microplates were read at $450 \mathrm{~nm}$ absorbance.

\section{Data Analysis}

Each experiment was repeated a minimum of three times, with triplicate determinations at each data point. Control media consisting of unstimulated THP-1 cells served as the negative control and was a blank. The negligible amount of cytokine secretion from the negative control was automatically subtracted from the cytokines secreted by monocytes incubated with LPS of periodontal pathogens. Mean values \pm SEM from triplicate samples were calculated and the significance of differences was assessed using a two-tailed Student's $t$-test. Differences in results with a $p$-value $<0.05$ were considered significant. 


\section{CHAPTER 4. RESULTS}

\section{Limulus Activity}

The endotoxin activities of LPS isolated from periodontal pathogens were measured first with the Limulus assay. ${ }^{51}$ Stock solutions of LPS preparations from E. coli, $F$. nucleatum, $P$. gingivalis, and $P$. denticola were prepared in sterile water at $10 \mathrm{ng} / \mathrm{ml}$. These solutions were placed in an ultrasonic bath for 20 seconds before use to ensure an uniform suspension. Samples of these LPS solutions were then tested for Endotoxin activity by their ability to cause gelation of Limulus amoebocyte lysate over a period of 60 minutes. This is a standard measure of LPS or Endotoxin activity. The Limulus assay uses a homogenate or lystate made from the macrophage-like amoebocytes taken from the blue blood (hemolymph) of the horseshoe crab (Limulus polyphemus). This lysate gels and becomes turbid in the presence of was measured at $450 \mathrm{~nm}$. This method has a high degree of sensitivity and can detect 0.001 to $100 \mathrm{ng} / \mathrm{ml}$ LPS. As a standard we have used $E$. coli LPS. The activity of each LPS sample in causing gelation of Limulus lysate was expressed in units corresponding to the activity of $1 \mathrm{ng} / \mathrm{ml}$ of $E$. coli LPS. The results (Figure 4-1) show that all four LPS preparations demonstrated measurable endotoxin activity. The endotoxin activity of $F$. nucleatum, and $P$. gingivalis, were almost identical, while the activity of $P$. denticola was slightly lower. The LPS activity of periodontal pathogens both had about one-third activity of the highly purified E. coli LPS standard.

\section{Influence of Periodontal Pathogens' LPS on MIP-1 $\alpha$ Secretion by Monocytes}

This study demonstrated in repeated experiments that MIP- $1 \alpha$ is induced by monocytes in response to stimulation by the LPS of periodontal pathogens. The data demonstrated that there were differences in the rate of secretion of MIP-1 $\alpha$. Upon comparing the rate of secretion of MIP-1 $\alpha$ among the three periodontal pathogens and $E$. coli it was found that MIP-1 $\alpha$ stimulation varied dependent upon the LPS of the specific organism stimulating the monocytes. We demonstrated that $F$. nucleatum LPS stimulated the secretion of MIP-1 $\alpha$. However, $P$. gingivalis and $P$. denticola inhibited the secretion of MIP-1 $\alpha$. Changes in the rate of secretion for MIP-1 $\alpha$ was directly correlated with the concentration of LPS from periodontal pathogens.

Figure 4-2 shows the secretion of MIP-1 $\alpha$ by monocytes to be dose-dependent upon the concentration of the $P$. gingivalis LPS. The higher concentrations of $P$. gingivalis LPS lead to an inhibition of MIP-1 $\alpha$ secretion from monocytes. When the monocytes were treated with the LPS of $P$. gingivalis at a concentration of $1 \mathrm{ng} / \mathrm{ml}$ the amount of MIP-1 $\alpha$ secreted was $73 \mathrm{pg} / \mathrm{ml}$, at a concentration of $5 \mathrm{ng} / \mathrm{ml}$ the amount of MIP-1 $\alpha$ secreted was $50 \mathrm{pg} / \mathrm{ml}$, at a concentration of $10 \mathrm{ng} / \mathrm{ml}$ the amount of MIP-1 $\alpha$ secreted was $11 \mathrm{pg} / \mathrm{ml}$ and at a the highest concentration of $20 \mathrm{ng} / \mathrm{ml}$ the average MIP- $1 \alpha$ secreted was $9 \mathrm{pg} / \mathrm{ml}$. This plot demonstrates a significant decrease in the stimulation of MIP-1 $\alpha$ from the $1 \mathrm{ng} / \mathrm{ml}$ to $20 \mathrm{ng} / \mathrm{ml}$ concentrations. 


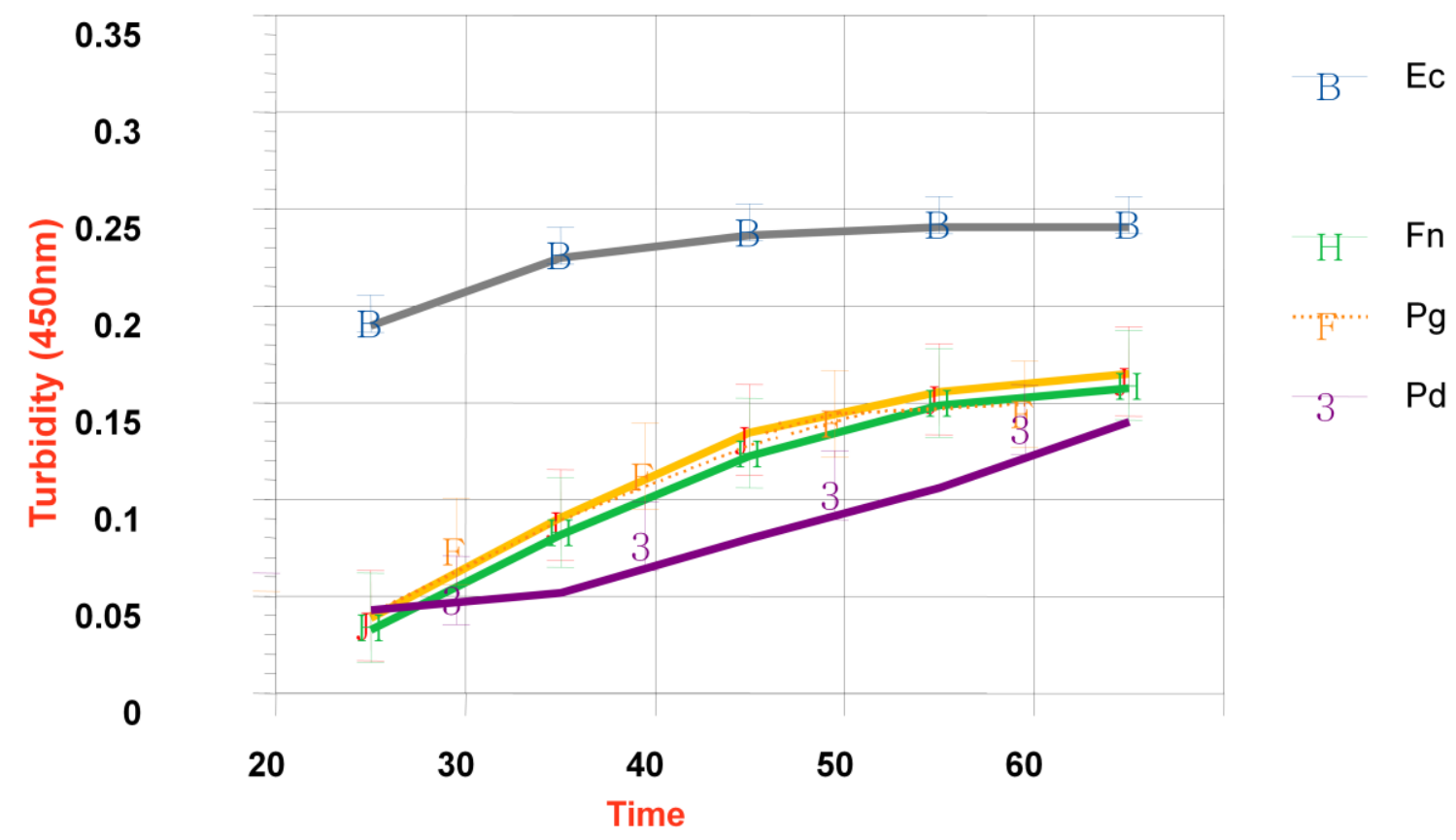

Figure 4-1. Endotoxin Activity of LPS Preparations from E. coli and Oral Pathogens at 10ng/ml. 


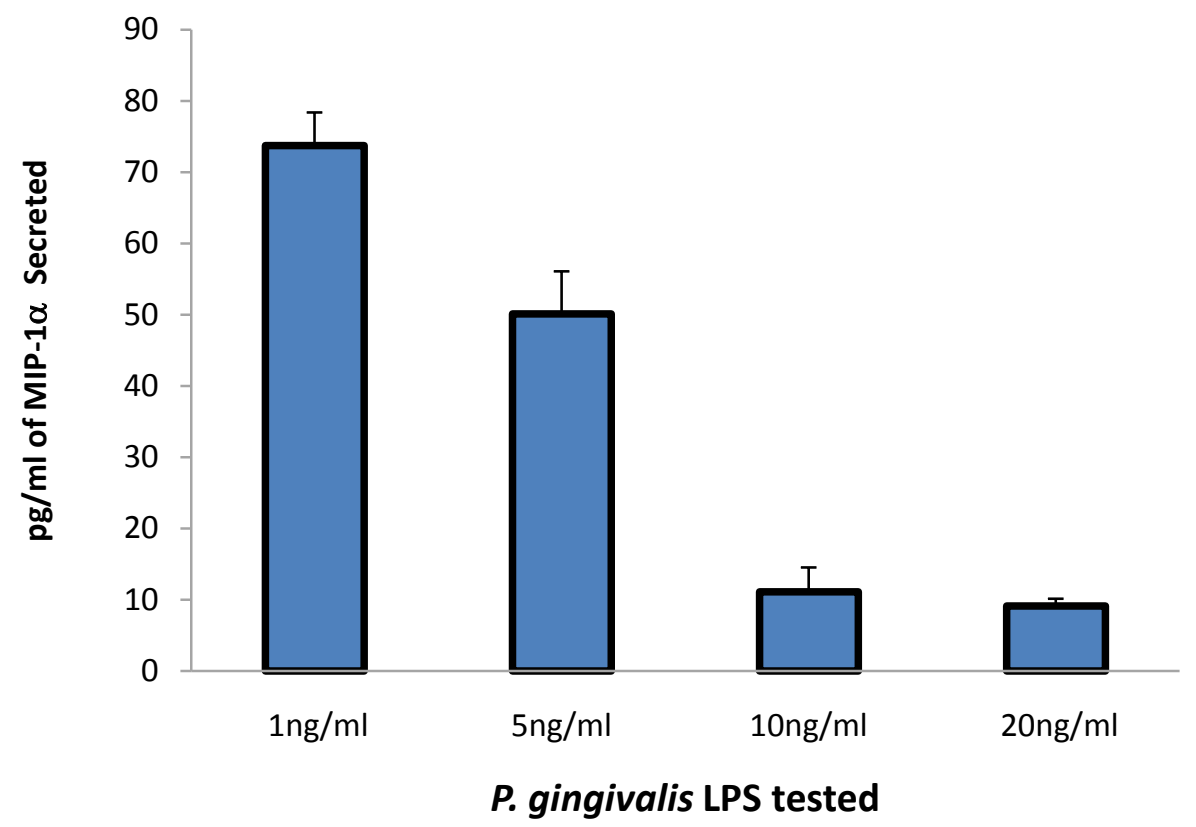

Figure 4-2. Demonstration of Effect of Porphyromonas gingivalis LPS Concentration on MIP-1a Secretion.

MIP-1 $\alpha$ secretion by monocytes was found to be inhibited by LPS of $P$. gingivalis at greater concentrations. The results are the mean \pm the standard error, $\mathrm{N}=3$ run in triplicate. 
Figure 4-3 shows the secretion of MIP-1 $\alpha$ by monocytes that were incubated with $1 \mathrm{ng} / \mathrm{ml}, 5 \mathrm{ng} / \mathrm{ml}, 10 \mathrm{ng} / \mathrm{ml}$, and $20 \mathrm{ng} / \mathrm{ml}$ concentrations of LPS isolated from $P$.

denticola. The secretion of MIP-1 $\alpha$ is dose dependent and as the concentrations of the LPS of $P$. denticola increased there is less stimulation of MIP- $1 \alpha$ secretion. When the monocytes were treated with the LPS of $P$. denticola at a concentration of $1 \mathrm{ng} / \mathrm{ml}$ the amount of MIP-1 $\alpha$ secreted was $73 \mathrm{pg} / \mathrm{ml}$, at a concentration of $5 \mathrm{ng} / \mathrm{ml}$ the amount of MIP-1 $\alpha$ secreted was $54 \mathrm{pg} / \mathrm{ml}$, at a concentration of $10 \mathrm{ng} / \mathrm{ml}$ the amount of MIP-1 $\alpha$ secreted was $24 \mathrm{pg} / \mathrm{ml}$ and at a the highest concentration of $20 \mathrm{ng} / \mathrm{ml}$ the average MIP-1 $\alpha$ secreted was $11 \mathrm{pg} / \mathrm{ml}$. This plot demonstrates a significant decrease in the stimulation of MIP-1 $\alpha$ from the $1 \mathrm{ng} / \mathrm{ml}$ to $20 \mathrm{ng} / \mathrm{ml}$ concentrations.

Figure 4-4 shows the secretion of MIP-1 $\alpha$ by monocytes that were incubated with $1 \mathrm{ng} / \mathrm{ml}, 5 \mathrm{ng} / \mathrm{ml}, 10 \mathrm{ng} / \mathrm{ml}$, and $20 \mathrm{ng} / \mathrm{ml}$ concentrations of LPS isolated from $F$. nucleatum. The secretion of MIP- $1 \alpha$ is dose dependent and as the concentrations of the LPS of $F$. nucleatum increases there is greater stimulation of MIP-1 $\alpha$ secretion. When the monocytes were treated with the LPS of $F$. nucleatum at a concentration of $1 \mathrm{ng} / \mathrm{ml}$ the amount of MIP-1 $\alpha$ secreted was $53 \mathrm{pg} / \mathrm{ml}$, at a concentration of $5 \mathrm{ng} / \mathrm{ml}$ the amount of MIP-1 $\alpha$ secreted was $64 \mathrm{pg} / \mathrm{ml}$, at a concentration of $10 \mathrm{ng} / \mathrm{ml}$ the amount of MIP-1 $\alpha$ secreted was $70 \mathrm{pg} / \mathrm{ml}$ and at a the highest concentration of $20 \mathrm{ng} / \mathrm{ml}$ the average MIP-1 $\alpha$ secreted was $77 \mathrm{pg} / \mathrm{ml}$.

Figure 4-5 shows the secretion of MIP-1 $\alpha$ by monocytes that were incubated with $1 \mathrm{ng} / \mathrm{ml}, 5 \mathrm{ng} / \mathrm{ml}, 10 \mathrm{ng} / \mathrm{ml}$, and $20 \mathrm{ng} / \mathrm{ml}$ concentrations of LPS isolated from E. coli. The secretion of MIP- $1 \alpha$ is dose dependent and as the concentrations of the LPS of $E$. coli increases there is greater stimulation of MIP- $1 \alpha$ secretion. When the monocytes were treated with the LPS of $E$. coli at a concentration of $1 \mathrm{ng} / \mathrm{ml}$ the amount of MIP- $1 \alpha$ secreted was $25 \mathrm{pg} / \mathrm{ml}$, at a concentration of $5 \mathrm{ng} / \mathrm{ml}$ the amount of MIP-1 $\alpha$ secreted was $55 \mathrm{pg} / \mathrm{ml}$, at a concentration of $10 \mathrm{ng} / \mathrm{ml}$ the amount of MIP-1 $\alpha$ secreted was $73 \mathrm{pg} / \mathrm{ml}$ and at a the highest concentration of $20 \mathrm{ng} / \mathrm{ml}$ the average MIP-1 $\alpha$ secreted was $91 \mathrm{pg} / \mathrm{ml}$.

Figure 4-6 summarizes the secretion of MIP-1 $\alpha$ by monocytes that were incubated with $1 \mathrm{ng} / \mathrm{ml}, 5 \mathrm{ng} / \mathrm{ml}, 10 \mathrm{ng} / \mathrm{ml}$, and $20 \mathrm{ng} / \mathrm{ml}$ concentrations of LPS isolated from periodontal pathogens. The experiments demonstrated similarities between the LPS of $P$. gingivalis and $P$. denticola. The LPS of these organisms inhibited the secretion of MIP-1 $\alpha$. As the LPS concentration of both $P$. gingivalis and $P$. denticola increased MIP$1 \alpha$ secretion decreased significantly as compared to MIP-1 $\alpha$ secretion via the stimulation of monocytes with E. coli or F nucleatum LPS. F. nucleatum and E. coli. LPS demonstrated similar results, the LPS of these organism resulted in an increase in the secretion of MIP-1 alpha at higher concentrations. However, there were no statistical differences in the ability of $F$. nucleatum and $E$. coli LPS to stimulate the secretion of MIP-1 $\alpha$ cultured monocytes.

Figure 4-7 shows the secretion of MIP-1 $\alpha$ by monocytes that were incubated with a LPS combination consisting of $10 \mathrm{ng} / \mathrm{ml} F$. nucleatum LPS with $5 \mathrm{ng} / \mathrm{ml} P$. denticola LPS, or with $10 \mathrm{ng} / \mathrm{ml} P d$ LPS. This experiment demonstrated that stimulation of MIP-1 $\alpha$ 


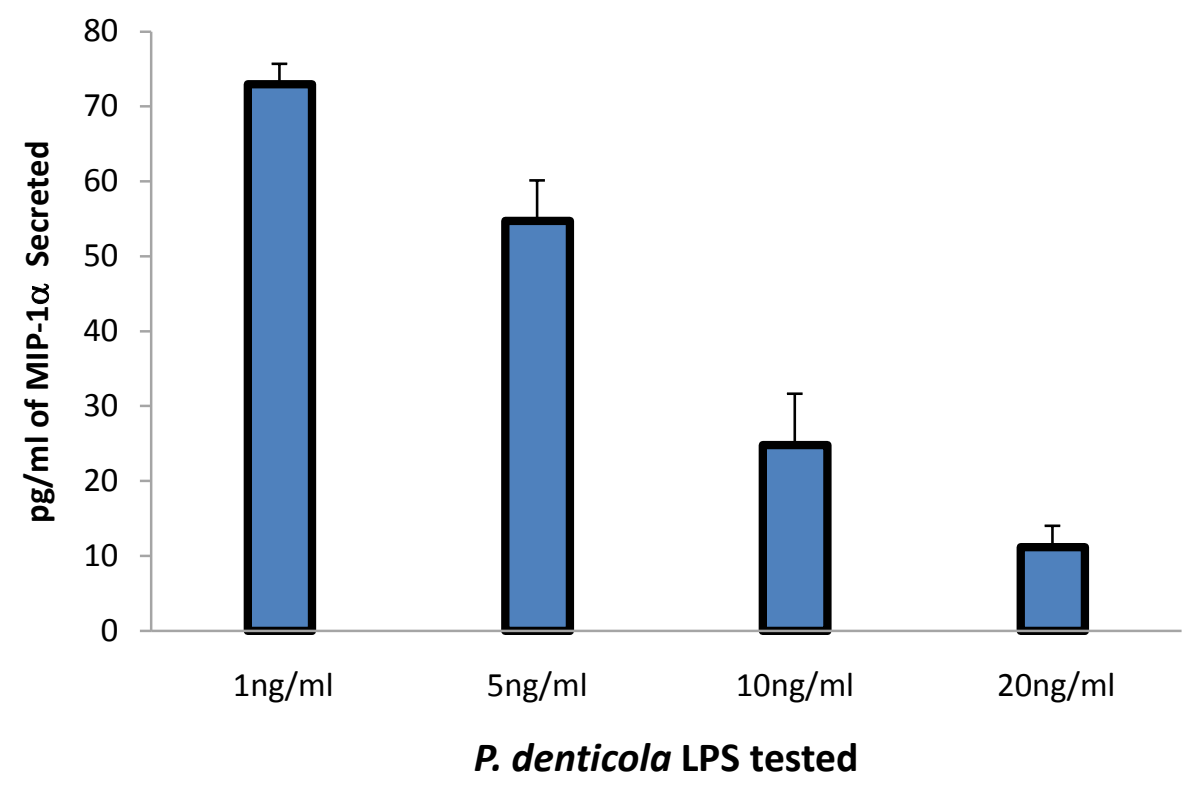

Figure 4-3. Demonstration of Effect of Prevotella denticola LPS Concentration on MIP-1 $\alpha$ Secretion.

MIP-1 $\alpha$ secretion by monocytes was found to be inhibited by LPS of $P$. denticola at greater concentrations. The results are the mean \pm the standard error, $\mathrm{N}=3$ run in triplicate. 


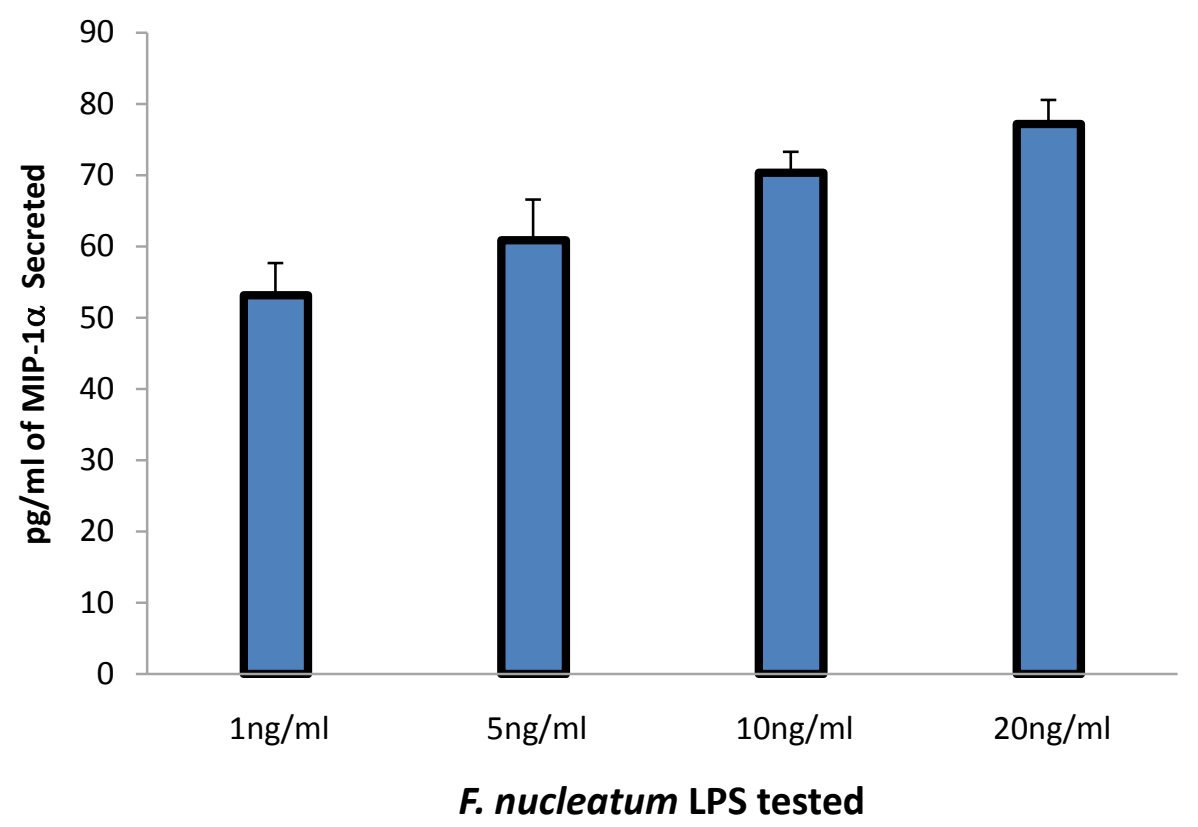

Figure 4-4. Demonstration of Effect of Fusobacterium nucleatum LPS Concentration on MIP-1a Secretion.

MIP-1 $\alpha$ secretion by monocytes was found to be stimulated by LPS of $F$. nucleatum at greater concentrations. The results are the mean \pm the standard error, $\mathrm{N}=3$ run in triplicate. 


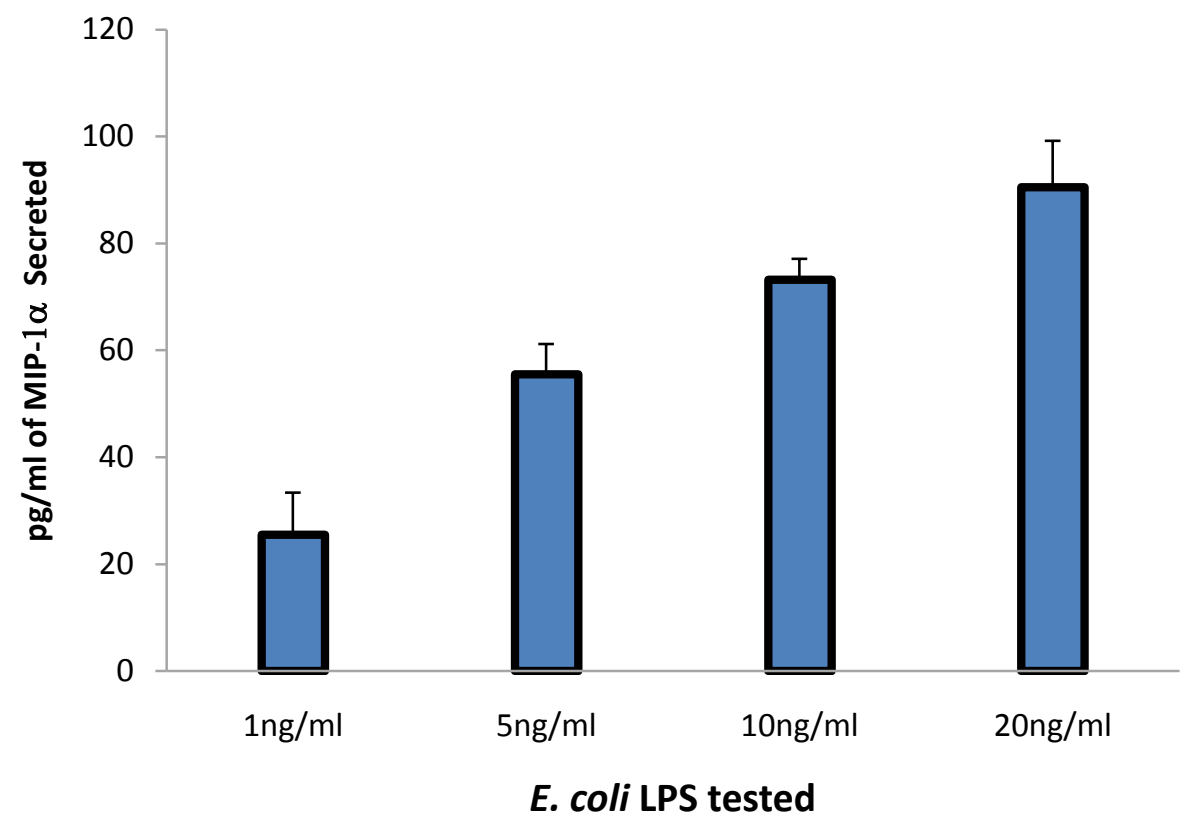

Figure 4-5. Demonstration of Effect of $E$. coli LPS Concentration on MIP-1a Secretion.

MIP-1 $\alpha$ secretion by monocytes was found to be stimulated by LPS of $E$. coli at greater concentrations. The results are the mean \pm the standard error, $\mathrm{N}=3$ run in triplicate. 


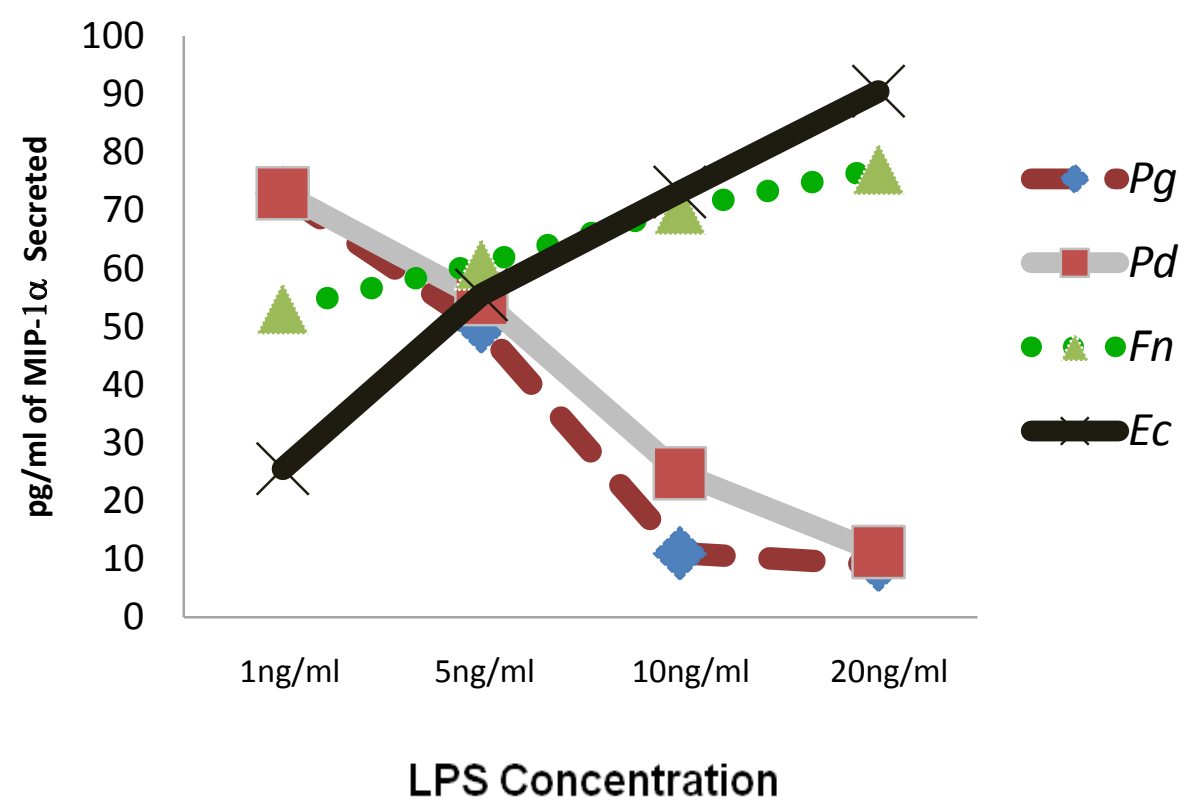

Figure 4-6. Demonstration of Effect of Periodontal Pathogen LPS Concentration on MIP-1a Secretion.

MIP-1 $\alpha$ secretion by monocytes was found to be stimulated by LPS of $F$. nucleatum and E. coli at greater concentrations. While at the same time MIP-1 $\alpha$ secretion was inhibited by the LPS of $P$. gingivalis and $P$. denticola at greater concentrations. 


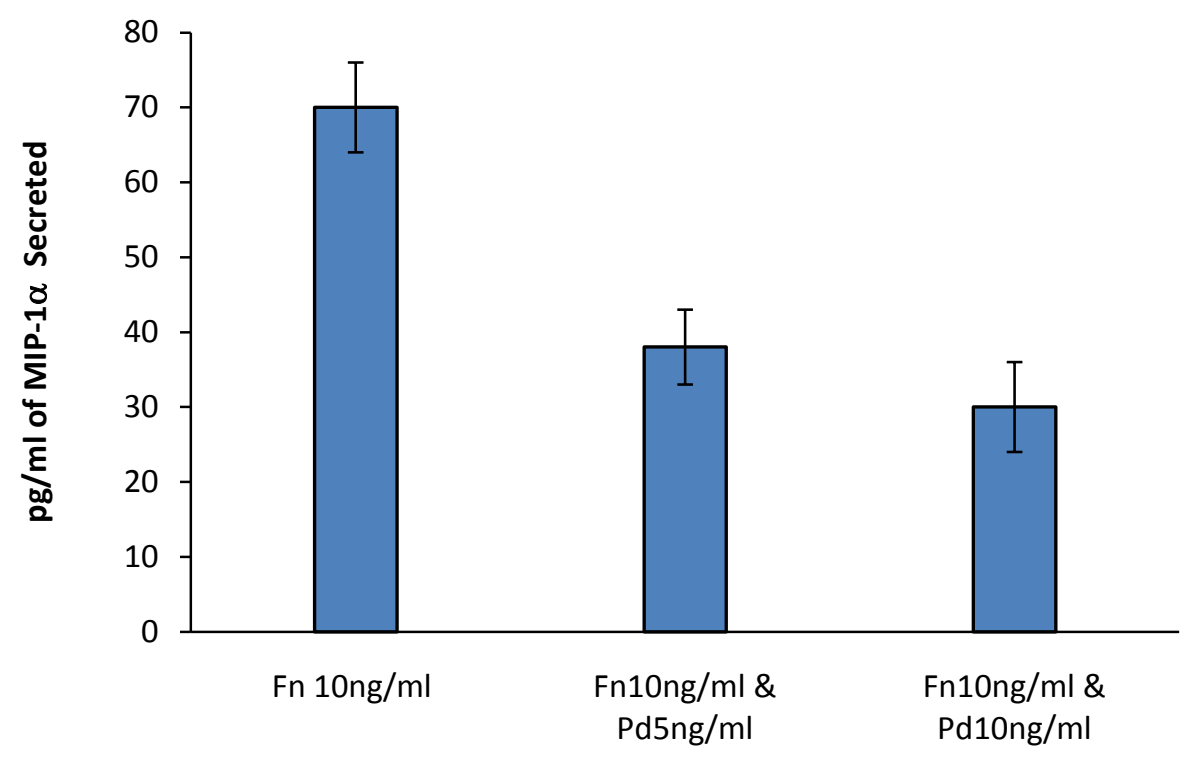

F. nucleatum LPS combined with P. denticola LPS tested.

Figure 4-7. Demonstration of Effect of Fusobacterium nucleatum LPS Combined with Prevotella denticola LPS on MIP-1a Secretion.

The stimulation of MIP-1 $\alpha$ secretion from monocytes by Fn LPS was found to be inhibited by combining the LPS of $F$. nucleatum with the LPS of $P$. denticola. 
secretion previously seen with $F$. nucleatum LPS is inhibited when in combination with $P$. denticola LPS. When the monocytes were treated with a combination of $10 \mathrm{ng} / \mathrm{ml}$ $F$. nucleatum LPS and $5 \mathrm{ng} / \mathrm{ml} P$. denticola LPS the amount of MIP- $1 \alpha$ secreted was 32 $\mathrm{pg} / \mathrm{ml}$, when treated with a combination of $10 \mathrm{ng} / \mathrm{ml} F$. nucleatum LPS and $10 \mathrm{ng} / \mathrm{ml} P$. denticola LPS the amount of MIP- $1 \alpha$ secreted was $3 \mathrm{pg} / \mathrm{ml}$. There is a significant reduction in the amount of MIP-1 $\alpha$ secreted when $F$. nucleatum LPS is combined with $P$. denticola LPS as compared to the secretion of MIP-1 $\alpha$ by monocytes when stimulated solely with $F$. nucleatum LPS. Also this experiment demonstrated a trend where higher concentrations of $P$. denticola LPS when combined with $F$. nucleatum LPS demonstrated a greater reduction in the secretion of MIP-1 $\alpha$. However, there was no statistical difference in the secretion of MIP- $1 \alpha$ between the varying concentrations of $P$. denticola LPS.

Figure 4-8 shows the secretion of MIP-1 $\alpha$ by monocytes that were incubated with a LPS combination consisting of $10 \mathrm{ng} / \mathrm{ml} F$. nucleatum LPS with $5 \mathrm{ng} / \mathrm{ml} P$. gingivalis LPS, and $10 \mathrm{ng} / \mathrm{ml} P$. gingivalis LPS. This experiment demonstrated that stimulation of MIP-1 $\alpha$ secretion previously seen with $F$. nucleatum LPS is inhibited when in combination with $P$. gingivalis LPS. When the monocytes were treated with a combination of $10 \mathrm{ng} / \mathrm{ml} F$. nucleatum LPS and $5 \mathrm{ng} / \mathrm{ml} P$. gingivalis LPS the amount of MIP-1 $\alpha$ secreted was $55 \mathrm{pg} / \mathrm{ml}$, when treated with a combination of $10 \mathrm{ng} / \mathrm{ml} F$. nucleatum LPS and $10 \mathrm{ng} / \mathrm{ml} P$. gingivalis LPS the amount of MIP-1 $\alpha$ secreted was 10 $\mathrm{pg} / \mathrm{ml}$. There is a significant reduction in the amount of MIP-1 $\alpha$ secreted when $F$. nucleatum LPS is combined with $P$. gingivalis LPS as compared to the secretion of MIP-1 $\alpha$ by monocytes when stimulated solely with $F$. nucleatum LPS. Also this experiment demonstrated a trend where higher concentrations of $P$. gingivalis LPS when combined with $F$. nucleatum LPS demonstrated a greater reduction in the secretion of MIP-1 $\alpha$. However, there was no statistical difference in the secretion of MIP-1 $\alpha$ between the varying concentrations of $P$. gingivalis LPS.

Figure 4-9 shows the secretion of MIP-1 $\alpha$ by monocytes that were incubated with a LPS combination consisting of $10 \mathrm{ng} / \mathrm{ml} F$. nucleatum LPS with $10 \mathrm{ng} / \mathrm{ml} P$. gingivalis LPS. In this experiment the cultured monocytes were stimulated first with $F$. nucleatum LPS and after 15, 30, and 60 minutes, $P$. gingivalis LPS was added to the cells. This experiment demonstrated that stimulation of MIP-1 $\alpha$ secretion previously seen with $F$. nucleatum LPS is inhibited when in combination with $P$. gingivalis LPS. However, as you increased the amount of time before the addition of $P$. gingivalis LPS, the monocytes were stimulated and secreted greater concentrations MIP-1 $\alpha$. The increased secretion of MIP- $1 \alpha$ is directly correlated with the time delay. The longer the wait before the addition of $P$. gingivalis LPS the greater the secretion of MIP-1 $\alpha$.

\section{Influence of Periodontal Pathogens on Monocytes to Secrete IL-8}

The goal of these experiments was to determine whether IL-8 is induced by monocytes in response to stimulation by the LPS of periodontal pathogens and to determine if there are any differences in the rate of secretion IL-8. The amount of IL-8 


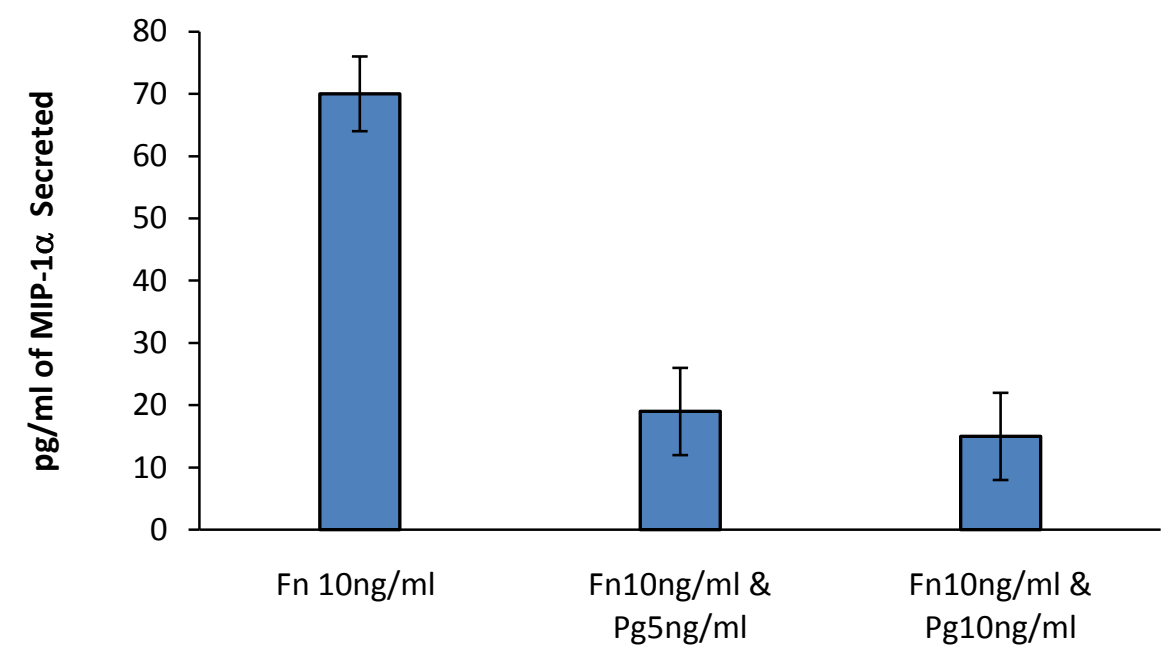

F. nucleatum LPS combined with $P$. ginigivalis LPS tested.

Figure 4-8. Demonstration of Effect of Fusobacterium nucleatum LPS Combined with Porphyromonas gingivalis LPS on MIP-1a Secretion.

The stimulation of MIP- $1 \alpha$ secretion from monocytes by $F$. nucleatum LPS was found to be inhibited by combining the LPS of $F$. nucleatum with the LPS of $P$. gingivalis. 


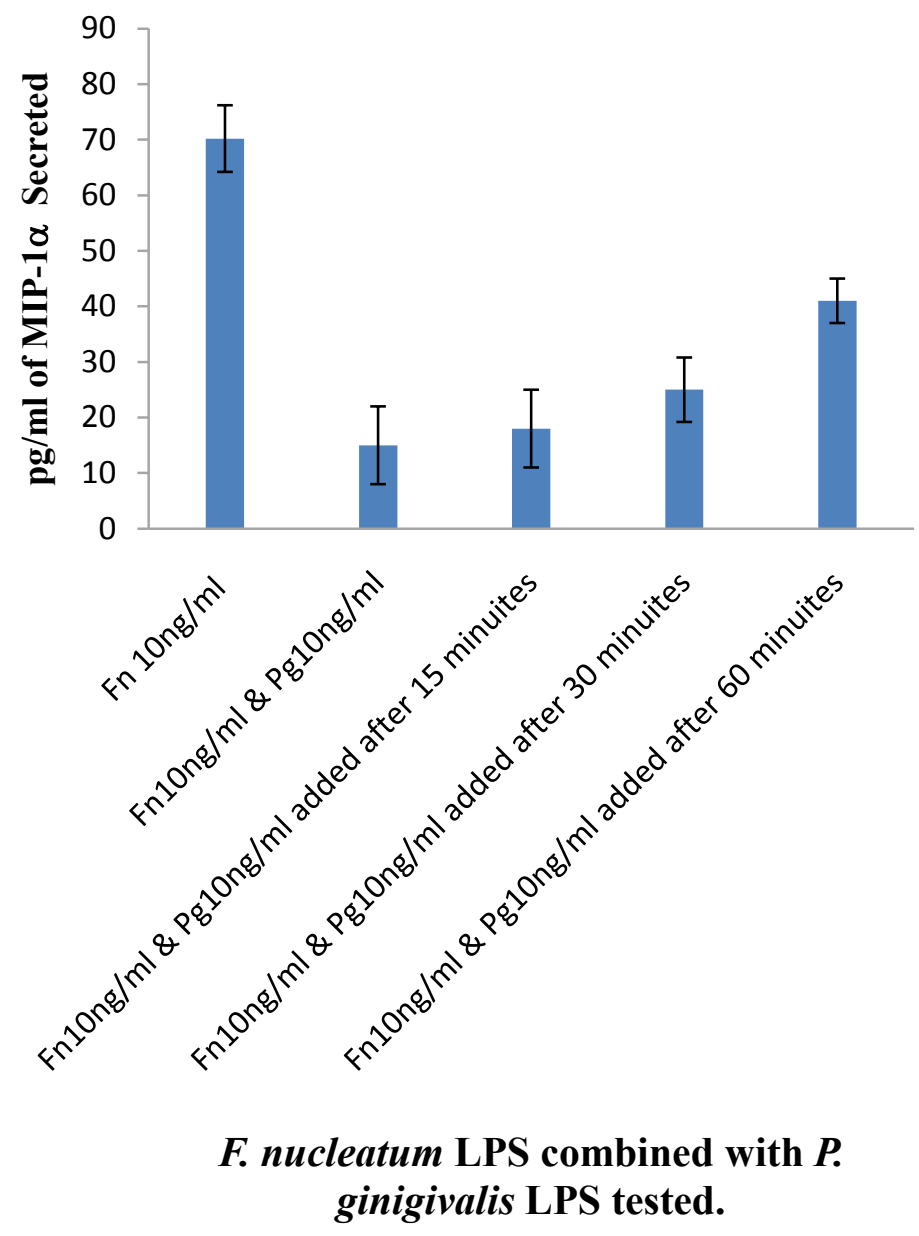

Figure 4-9. Demonstration of Effect of Fusobacterium nucleatum LPS Combined with Porphyromonas gingivalis LPS at Timed Interval on MIP-1 $\alpha$ Secretion.

The stimulation of MIP- $1 \alpha$ secretion from monocytes by a combination of $F$. nucleatum LPS and $P$. gingivalis LPS was found to stimulate the secretion of MIP- $1 \alpha$ when the $P$. gingivalis was added at delayed time intervals. 
secreted by the three periodontal pathogens selected was compared. LPS isolated from $P$. gingivalis, $P$. denticola, and $F$. nucleatum was added to the cultured monocytes and the supernatants were assayed for the secretion of IL- 8 by ELISA. E. coli LPS served as the positive control, and unstimulated cultured monocytes served as the negative control.

\section{IL-8 Secretion by THP-1 Cells in Response to LPS of Periodontal Pathogens}

IL-8 is a cytokine produced by macrophages with a potency as a chemotactic factor equal to that of C5a. It has been demonstrated that IL-8 is a pro-inflammatory mediator of gingivitis. In addition it is one of the major mediators of the inflammatory response, by serving as a chemical signal that attracts neutrophils to sites of infection. The goals of these experiments were to determine whether the isolated LPS from the periodontal pathogens would stimulate the THP-1 cells to secrete IL-8 and to quantify the amount of IL-8 secreted by the THP-1 cells. An ELISA assay from was employed to measure the concentration of IL-8 released from the THP-1 cells when stimulated with the LPS of $P$. gingivalis, $P$. denticola, and $F$. nucleatum. Cultured monocytes were incubated with $1 \mathrm{ng} / \mathrm{ml}, 5 \mathrm{ng} / \mathrm{ml}, 10 \mathrm{ng} / \mathrm{ml}$, and $20 \mathrm{ng} / \mathrm{ml}$ of LPS isolated for each periodontal pathogen.

Figure 4-10 shows the secretion of IL- 8 by the monocytes to be dose-dependent upon the concentration of the LPS of $P$. gingivalis. As the concentrations of the LPS of $P$. gingivalis increases there is less stimulation of IL-8 secretion.

Figure 4-11 shows the secretion of IL-8 by monocytes that were incubated with $1,5,10$, and $20 \mathrm{ng} / \mathrm{ml}$ of LPS isolated from $P$. denticola. The secretion of IL-8 is dose dependent and as the concentrations of the LPS of $P$. denticola increases there is less stimulation of IL-8 secretion.

Figure 4-12 shows the secretion of IL-8 by monocytes that were incubated with, 5,10 , and $20 \mathrm{ng} / \mathrm{ml}$ of LPS isolated from F. nucleatum. The secretion of IL-8 is dose dependent and as the concentrations of the LPS of $F$. nucleatum increases there is greater stimulation of IL-8 secretion.

Figure 4-13 shows the secretion of IL-8 by monocytes that were incubated with $1,5,10$, and $20 \mathrm{ng} / \mathrm{ml}$ of LPS isolated from E. coli. The secretion of IL-8 is dose dependent and as the concentrations of the LPS of E. coli increases there is greater stimulation of IL-8 secretion.

Figure 4-14 summarizes the secretion of IL-8 by monocytes that were incubated with $1,5,10$, and $20 \mathrm{ng} / \mathrm{ml}$ of LPS isolated from periodontal pathogens. The secretion of IL-8 is inhibited by increasing concentrations of both $P$. gingivalis and $P$. denticola. In addition the secretion of IL-8 appears to be stimulated by increasing concentrations of $F$. nucleatum and E. coli, in a dose dependent manner. 


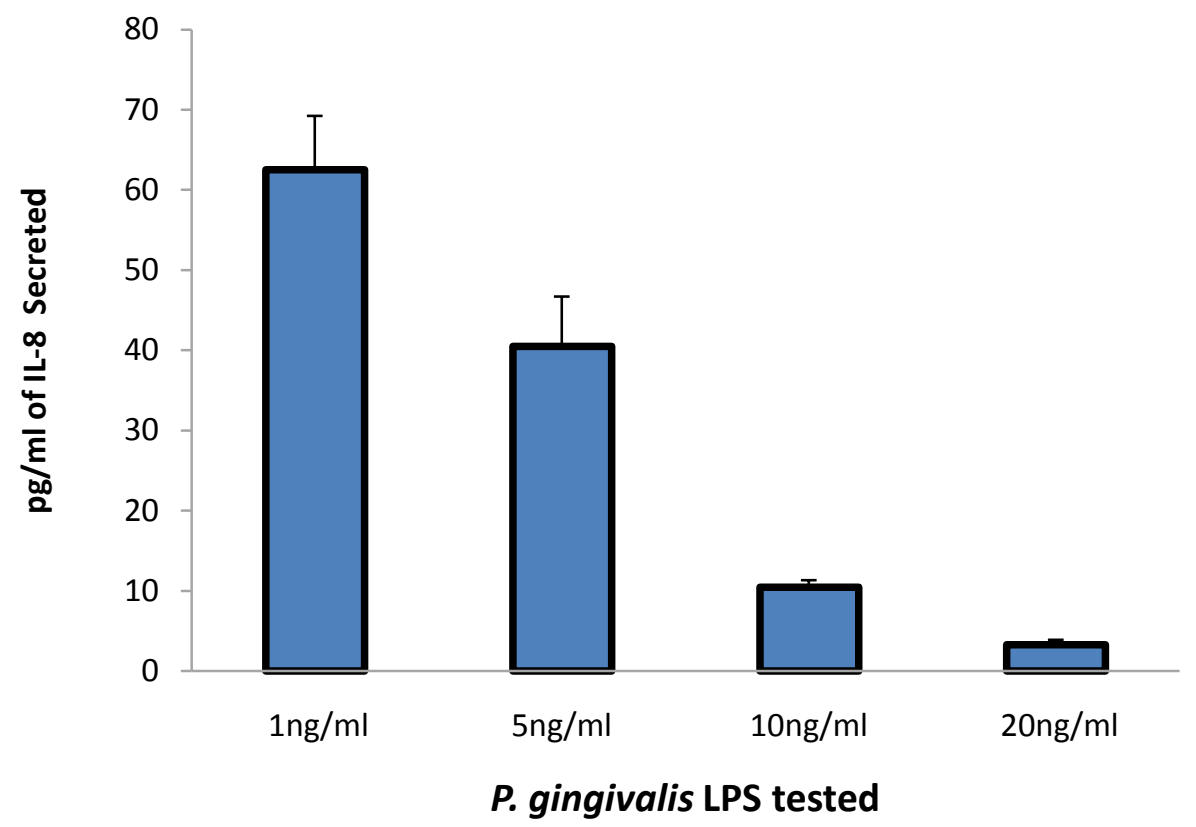

Figure 4-10. Demonstration of Effect of Porphyromonas gingivalis LPS Concentration on IL-8 Secretion.

IL-8 secretion by monocytes was found to be inhibited by LPS of $P$. gingivalis at greater concentrations. The results are the mean \pm the standard error, $\mathrm{N}=3$ run in triplicate. 


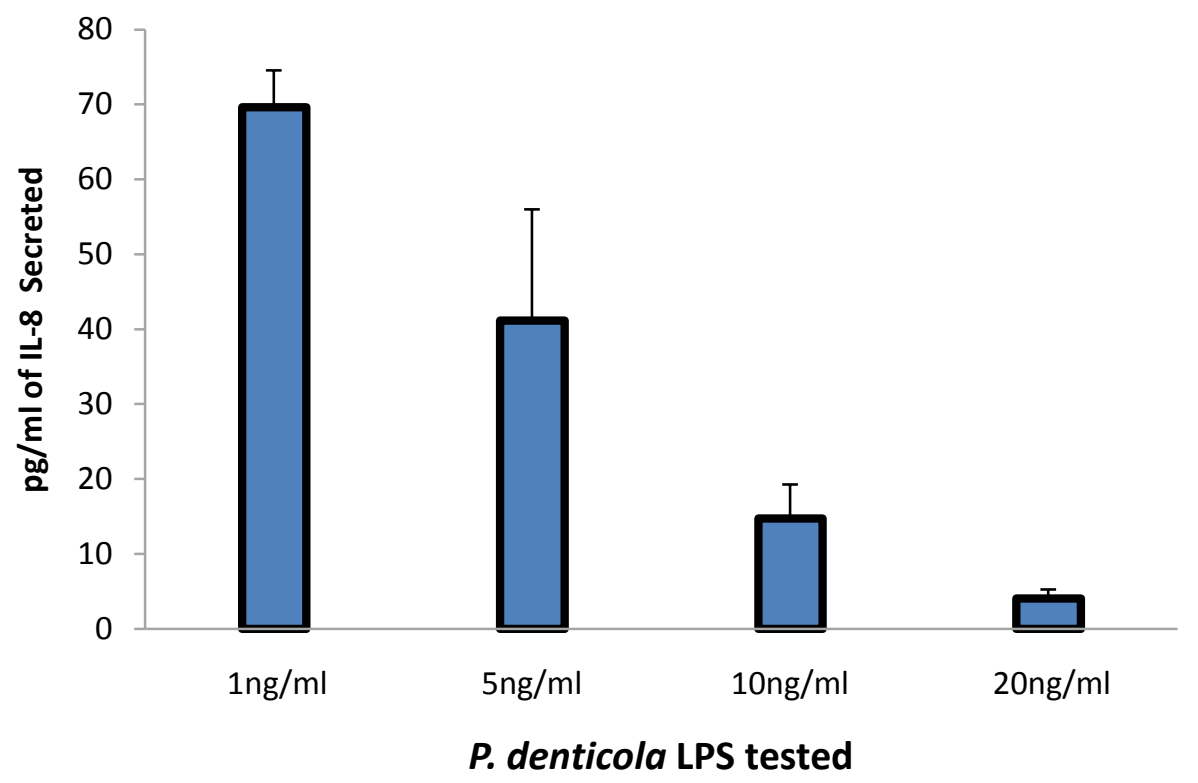

Figure 4-11. Demonstration of Effect of Prevotella denticola LPS Concentration on IL-8 Secretion.

IL-8 secretion by monocytes was found to be inhibited by LPS of $P$. denticola at greater concentrations. The results are the mean \pm the standard error, $\mathrm{N}=3$ run in triplicate. 


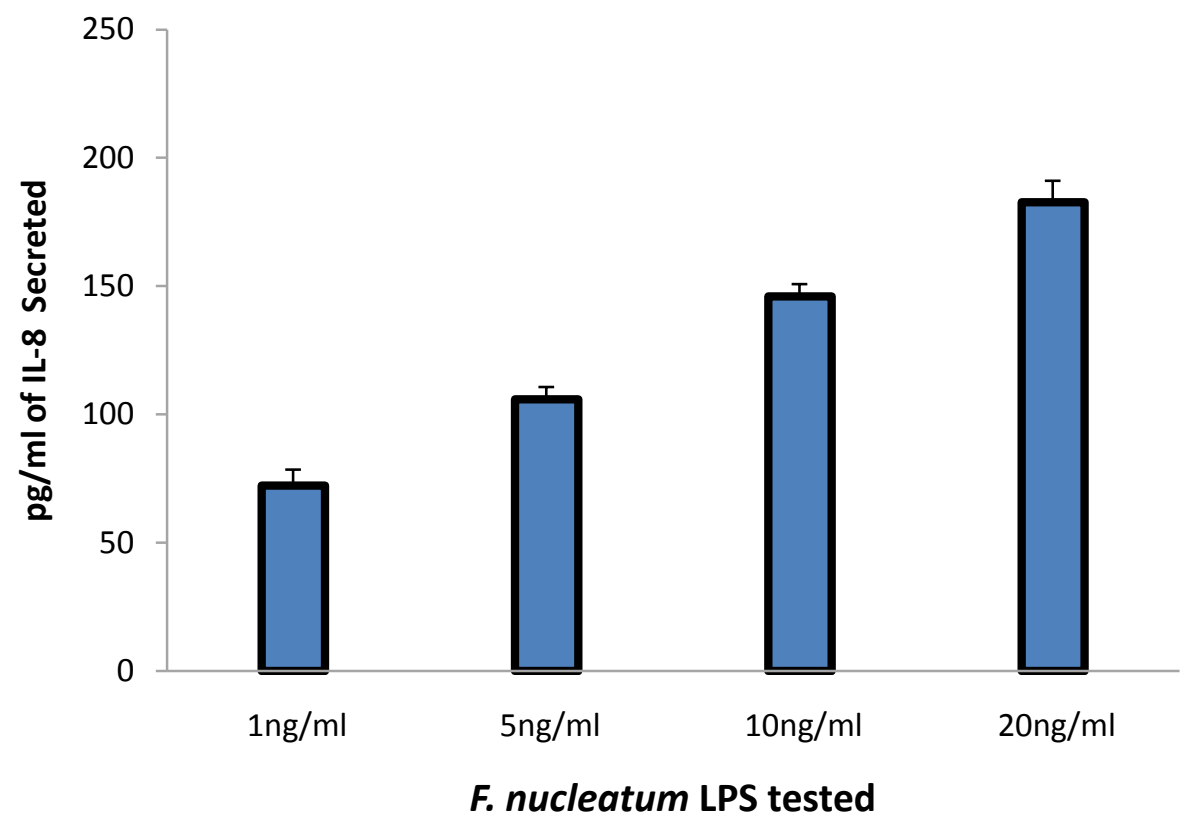

Figure 4-12. Demonstration of Effect of Fusobacterium nucleatum LPS Concentration on IL-8 Secretion.

IL-8 secretion by monocytes was found to be stimulated by LPS of $F$. nucleatum at greater concentrations. The results are the mean \pm the standard error, $\mathrm{N}=3$ run in triplicate. 


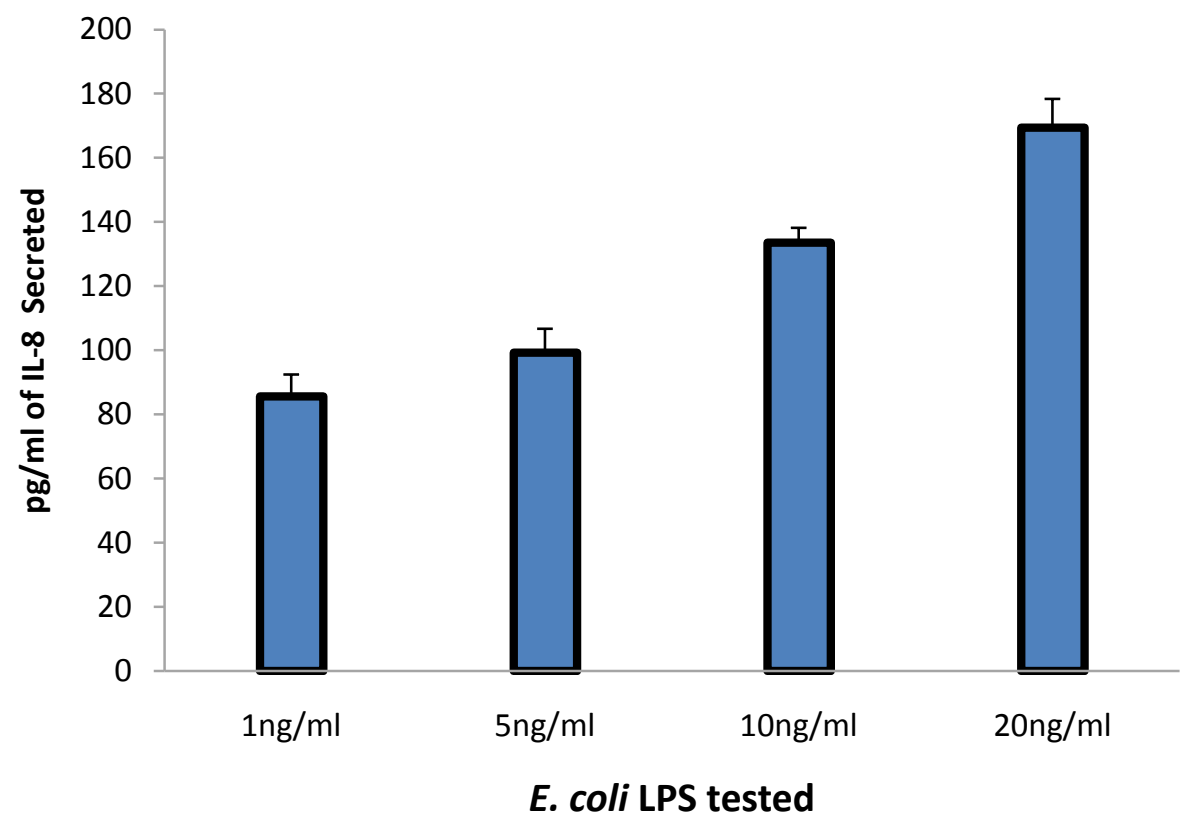

Figure 4-13. Demonstration of Effect of $E$. coli LPS Concentration on IL-8 Secretion.

IL-8 secretion by monocytes was found to be stimulated by LPS of E. coli at greater concentrations. The results are the mean \pm the standard error, $\mathrm{N}=3$ run in triplicate. 


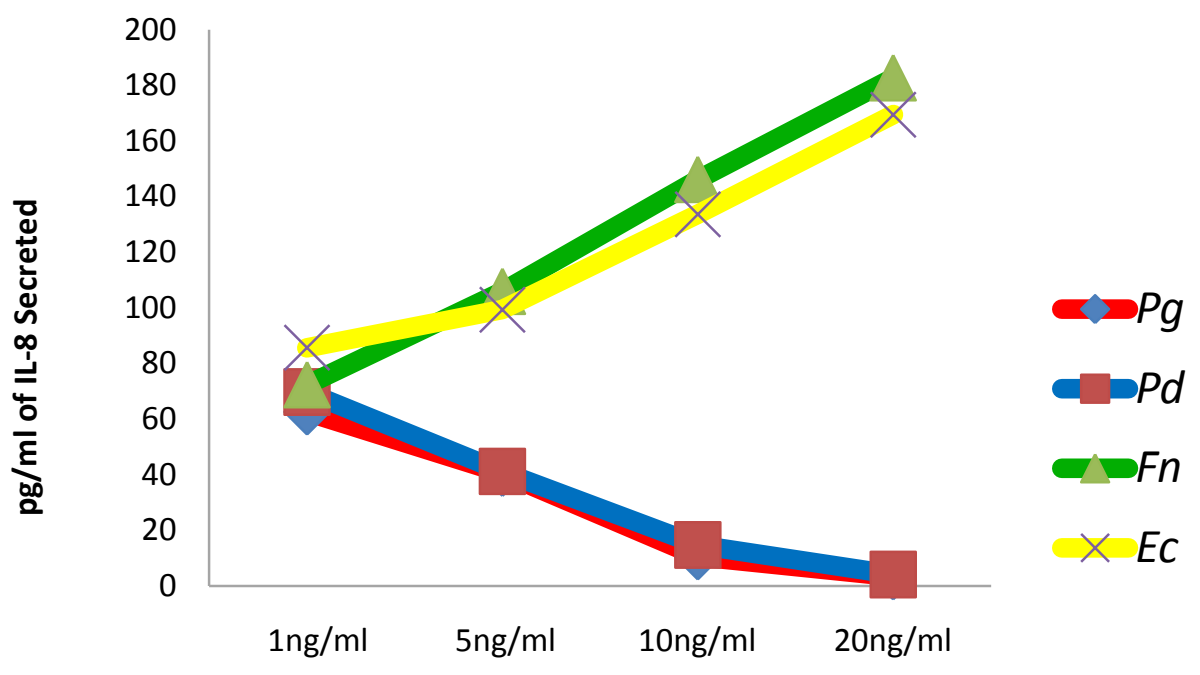

LPS Concentration

Figure 4-14. Demonstration of Effect of Periodontal Pathogen LPS Concentration on IL-8 Secretion.

IL-8 secretion by monocytes was found to be stimulated by LPS of $F$. nucleatum and E. coli at greater concentrations. While at the same time IL-8 secretion was inhibited by the LPS of $P$. gingivalis and $P$. denticola at greater concentrations. 


\section{Effect of Periodontal Pathogens LPS Combinations on Monocytes to Secrete IL-8}

In periodontal disease the periodontal pathogens are not found as individual strains but are found in combination with numerous organisms as part of a biofilm. The goal of these experiments was to determine whether IL-8 is induced by monocytes in response to stimulation by the LPS of periodontal pathogen combinations and to compare the effect of periodontal pathogen combinations on the rate of IL-8 secretion. The amount of IL-8 secreted by the combination of $F$. nucleatum LPS with $P$. gingivalis LPS, or F. nucleatum LPS with P. denticola LPS was compared to F. nucleatum LPS alone. Isolated LPS combinations were added to the cultured monocytes and the supernatants were assayed for the secretion of IL-8 by ELISA. E. coli LPS served as the positive control.

Figure 4-15 shows the secretion of IL- 8 by the monocytes to be stimulated by $F$. nucleatum LPS alone. However, upon combining the $F$. nucleatum LPS with $P$. gingivalis or $P$. denticola LPS there is an inhibition of IL-8 secretion. Furthermore the greater the concentration of either $P$. gingivalis or $P$. denticola the greater the inhibition of IL-8 secretion. The results indicate that the LPS of both $P$. gingivalis and $P$. denticola may have a greater affinity for the LPS binding site on the monocytes, than the LPS of $F$. nucleatum, thus causing the inhibition of cytokine secretion.

Figure 4-16 shows the secretion of IL-8 by monocytes that were incubated with a LPS combination consisting of $10 \mathrm{ng} / \mathrm{ml} F$. nucleatum LPS with $10 \mathrm{ng} / \mathrm{ml} P$. gingivalis LPS. In this experiment the cultured monocytes were stimulated first with $F$. nucleatum LPS and after 15, 30, and 60 minutes, $P$. gingivalis LPS was added to the cells. This experiment demonstrated that stimulation of IL-8 secretion previously seen with $F$. nucleatum LPS is inhibited when in combination with $P$. gingivalis LPS at baseline. However, as you increased the amount of time before the addition of $P$. gingivalis LPS, the monocytes were stimulated and secreted greater concentrations of IL-8. The increased secretion of IL- 8 is directly correlated with the time delay. The longer the wait before the addition of $P$. gingivalis LPS the greater the secretion of IL-8. The results showed that when the monocytes were first incubated with $F$. nucleatum LPS challenging with $P$. gingivalis LPS at a later time had no significant inhibitory effect on cells to secrete IL-

8. The data suggests that the two LPS molecules appears to bind to the same LPS binding site on the monocytes. 


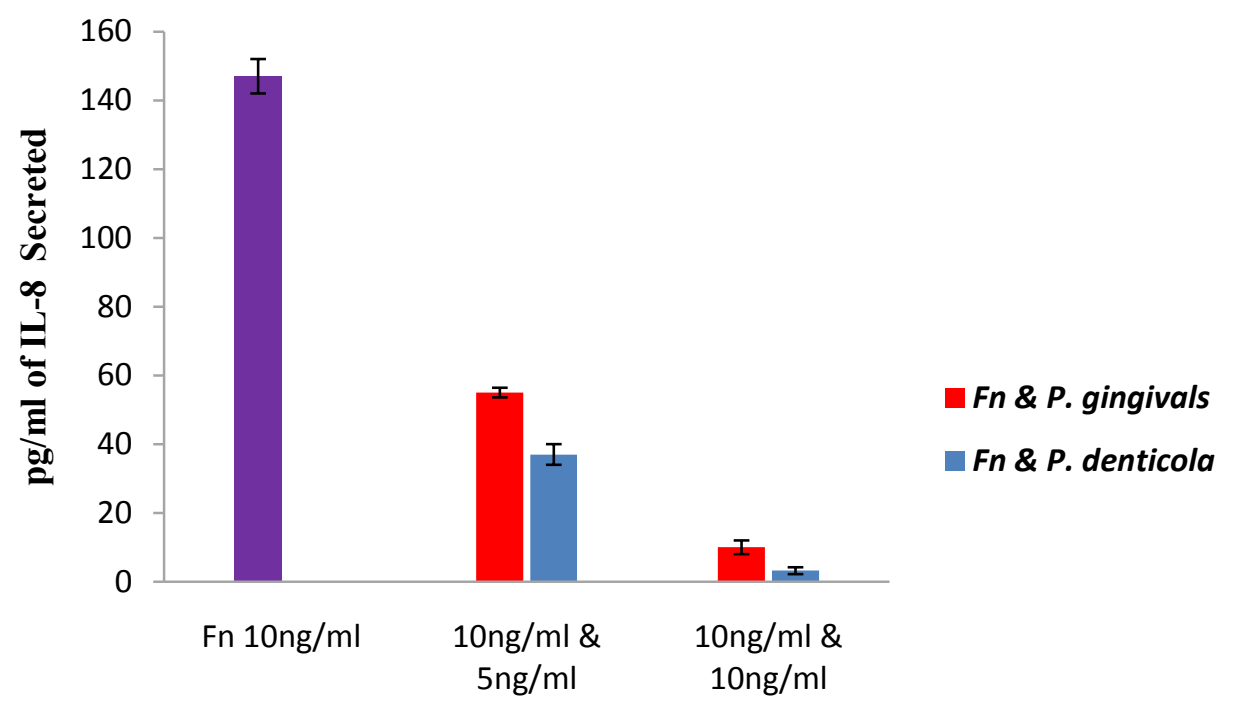

F. nucleatum LPS combined with either $P$. denticola or P. gingivalis LPS tested.

Figure 4-15. Demonstration of Effect of Fusobacterium nucleatum LPS in Combination with Porphyromonas gingivalis LPS or Prevotella denticola LPS Concentrations on IL-8 Secretion.

IL-8 secretion by monocytes was found to be stimulated by LPS of $F$. nucleatum. Upon combining $F$. nucleatum LPS with $P$. gingivalis or $P$. denticola LPS IL-8 secretion was inhibited. At greater concentrations of both $P$. gingivalis and $P$. denticola LPS there was greater inhibition of IL-8 secretion. 


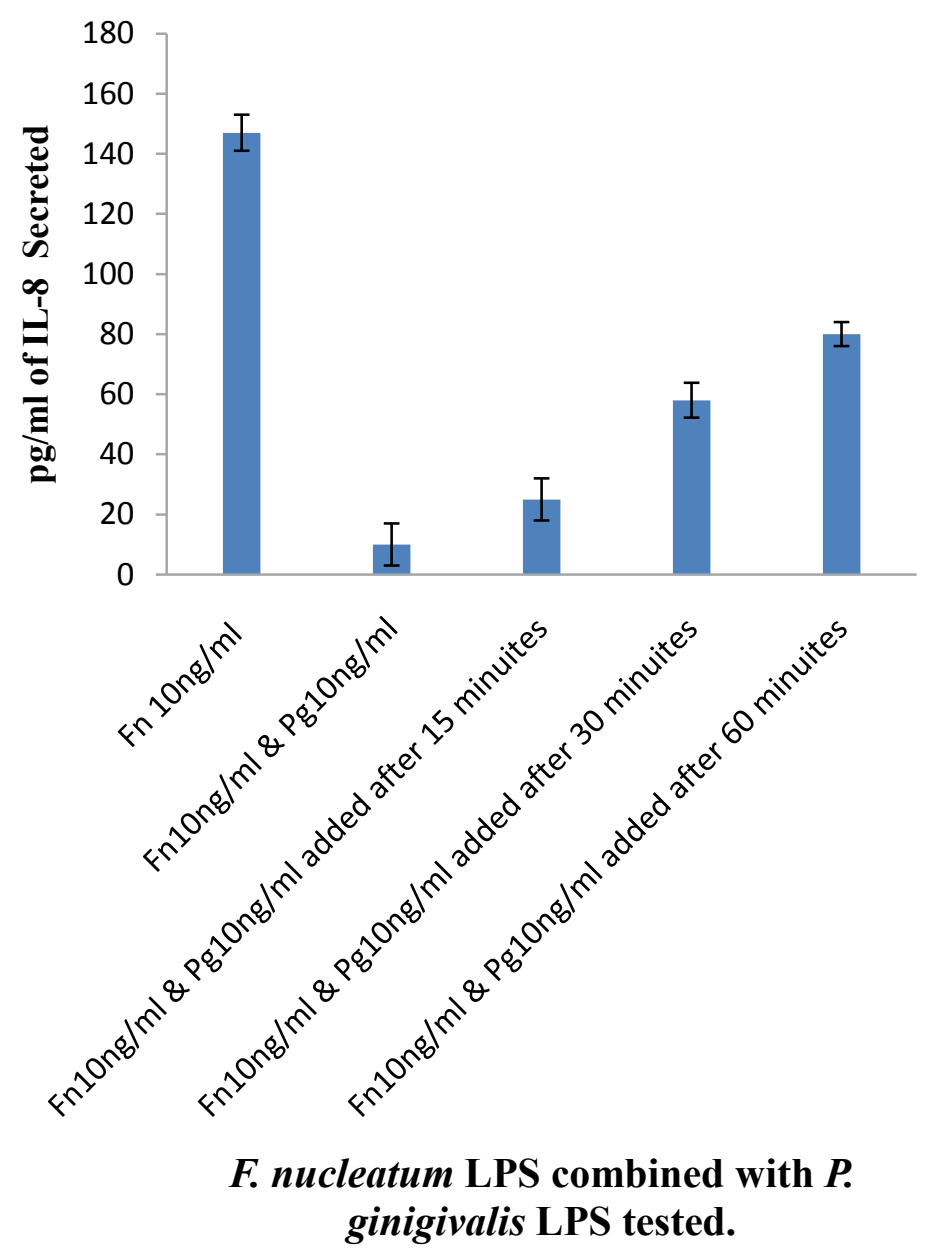

Figure 4-16. Demonstration of Effect of Fusobacterium nucleatum LPS Combined with Porphyromonas gingivalis LPS at Timed Interval on IL-8 Secretion.

The stimulation of IL-8 secretion from monocytes by a combination of $F$. nucleatum LPS and $P$. gingivalis LPS was found to stimulate the secretion of IL- 8 when the $P$. gingivalis was added at delayed time intervals. 


\section{CHAPTER 5. DISCUSSION}

The first line of defense against an infection consists of the recruitment of monocytes and neutrophils. These cells are the most common leukocytes in circulating blood, representing greater than fifty percent of the cells. In this study cultured monocytes were exposed to the LPS isolated from $P$. gingivalis, $P$. denticola, and $F$. nucleatum and the ability of the monocytes to secrete the cytokines IL- 8 and chemokine MIP-1 $\alpha$ was determined. It has been shown that the regulation of leukocyte migration into and through the tissues is determined by the expression of adhesion molecules, mainly on endothelial cells, which are induced by pro-inflammatory cytokines, as well as a group of cytokines with chemotactic properties, the chemokines. Chemokines are responsible for the recruitment and subsequent activation of particular leucocytes into inflamed tissues and therefore play a central role in the final outcome of the immune response by determining which subsets of leucocytes form the inflammatory infiltrate. $^{54}$

Previous studies conducted in our laboratory demonstrated differences in biological functions of LPS. LPS isolated from $P$. gingivalis, $P$. denticola and $P$. intermedia failed to prime neutrophils. Furthermore, these LPS molecules also inhibited production of superoxide ions by the neutrophils. On the other hand the LPS of $F$. nucleatum and E. coli both primed the neutrophils readily and had no negative effect on the production of superoxide ions. We hypothesized that pathogenic bacteria appear to be "stealthy" by avoiding stimulation of neutrophils thus escaping phagocytosis. Such "stealthy" nature of LPS would aid the pathogens to colonize the host gingival tissues readily, and cause tissue destruction.

The LPS samples isolated from three periodontal pathogens demonstrated very slightly diminished but similar endotoxin activity as E. coli when tested with the Limulus assay. The results showed that the LPS endotoxin activity of periodontal pathogens in general had lower endotoxin activity than the LPS of E. coli. It required at least 3-fold greater amount of LPS of periodontal pathogens to reach the level of activity attained by the LPS of $E$. coli. Studies have shown that the variation in endotoxin activity of LPS was attributed to the lipid A structure, which seems to vary among certain bacteria. ${ }^{53}$ Nevertheless, in the present study there were no differences in endotoxin activity between the three periodontal pathogens. Previous studies from our laboratory demonstrated that even though all the LPS preparations had similar endotoxin activity, their functions seem to differ from each other.

\section{The Secretion of MIP-1 $\alpha$ by THP-1 Cells in Response to LPS of Periodontal Pathogens}

MIP-1 $\alpha$ is a heparin-binding protein, with a molecular weight of 6-8 $\mathrm{kDa}$, known to exhibit a number of inflammatory and immunoregulatory activities. MIP-1 $\alpha$ is a member of a super family of cytokines called chemokines, and has been shown to 
mediate chemotactic activity for inflammatory and immune effector cells. MIP-1 $\alpha$ also plays a role in regulating hematopoiesis and stimulating production of other inflammatory mediators such as IL-1, TNF- $\alpha$, and histamine. ${ }^{37}$ While MIP- $1 \alpha$ was originally identified as a secretory product of endotoxin-stimulated mouse macrophages, these chemokines are produced by a variety of cell types including neutrophils, fibroblasts, endothelial and epithelial cells. ${ }^{39}$ In the present investigation we studied the secretion of MIP-1 $\alpha$ from cultured monocytes.

The results of our investigation demonstrated unique differences among the LPS of tested periodontal pathogens to stimulate MIP-1 $\alpha$ secretion from monocytes. The results showed lower concentrations of LPS from $P$. gingivalis and $P$. denticola induced the monocytes to secrete approximately twice as much MIP- $1 \alpha$ than that of $F$. nucleatum. However as the concentrations of LPS from $P$. gingivalis and $P$. denticola increased there was a significant degree of inhibition in the secretion of MIP-1 $\alpha$. From these results one would expect as periodontitis progresses and as higher concentrations of the pathogenic bacteria are cultured from sites of infections one would see a decrease in the secretion MIP-1 $\alpha$ due to $P$. gingivalis or $P$. denticola LPS stimulation.

In the literature extensive research has been carried out in the area of periodontal inflammatory mediators. There have been very few studies on the role of the host immune response in the presence of chemokines. There are a limited number of studies that correlate the extent and severity of periodontitis with the secretion of MIP-1 $\alpha$. Fine et $a{ }^{42}$ is one such study which looked at patients with periodontitis and measured the secretion of MIP-1 $\alpha$ from periodontally involved sites. They found a 50 fold increase in levels of MIP-1 $\alpha$ from the active sites as compared to non-active sites. This is contrary to what was observed in the present study. However some of the difference may be explained by the fact that in the study by Fine et al., patients at risk for aggressive periodontitis were reported and the organism cultured from these active sites was limited to $A a$. The organisms associated with this investigation included $P$. gingivalis, $F$. nucleatum, and $P$. denticola, which are associated more with chronic periodontitis as opposed to aggressive periodontitis. Studies by Hamada et al. have demonstrated the LPS of Gram-negative bacteria do differ structurally and functionally, and the bacteria can modify their structure to elude the host's immune defenses. ${ }^{55}$ This may explain why $P$. gingivalis and $P$. denticola LPS behaved differently than $F$. nucleatum LPS in this investigation and differently from $A a$ in the study by Fine et $a l .{ }^{42}$

Ryu examined the secretion of MIP- $1 \alpha$ in active peri-implantitis sites. ${ }^{44}$ It has been demonstrated that peri-implantitis sites have a bacterial profile comparable to chronic periodontitis sites. Ryu's study appears to agree with Fine et al., subjects with a higher plaque index demonstrated a greater secretion MIP-1 $\alpha$, and sites that demonstrated clinical evidence of peri-implantitis also presented with an increased secretion of MIP-1 $\alpha$. Owing to different study designs, there have been differences between some of the results of the present investigation and those of Ryu and Fine et al. Values were not comparable because of the conditions in which studies were conducted. 
In the present investigation the results demonstrated the degree of inhibition of MIP-1 $\alpha$ secretion by monocytes to be dose-dependent, with the higher concentration of LPS of $P$. gingivalis and $P$. denticola yielding greater inhibition of the monocytes ability to secrete MIP-1 $\alpha$. These results suggest that as the LPS from the more pathogenic bacteria may bind to the CD14 receptor and exert an inhibitory effect on the secretion of MIP- $1 \alpha$.

\section{The Secretion of IL-8 by THP-1 Cells in Response to LPS of Periodontal Pathogens}

IL-8 is a chemokine that is important in the regulation of the inflammatory response for its ability to recruit and activate acute inflammatory cells. It is able to mediate the activation and migration of neutrophils, giving it a central role in the defensive line against periodontal pathogens. IL- 8 can be induced by multiple stimuli including LPS, live bacteria, and pro-inflammatory cytokines such as TNF and IL- $1 .{ }^{45}$ It is secreted by a wide range of cells such as macrophages, monocytes, fibroblast, and epithelial cells. ${ }^{47}$ In the present investigation we examined the secretion of IL-8 from monocytes stimulated with LPS from $P$. gingivalis, $P$. denticola, and $F$. nucleatum.

The results of our investigation demonstrated unique differences among the LPS of tested periodontal pathogens to stimulate IL-8 secretion from monocytes. The results showed similar concentrations of LPS from $P$. gingivalis and $P$. denticola induced the monocytes to secrete IL-8 at $1 \mathrm{ng} / \mathrm{ml}$ concentrations. However as the concentrations of LPS from $P$. gingivalis and $P$. denticola increased, the secretion of IL- 8 was inhibited. The inhibition of IL-8 was a dose dependent inhibition with the greatest concentrations of LPS from $P$. gingivalis and $P$. denticola yielding the lowest secretion of IL-8. It is difficult to compare our results with other studies because of the degree of variation between our study and other studies. Many studies used cell types other than monocytes to measure the secretion of IL-8. Also variation in the LPS isoform used in different studies was often unclear. Coats et al. demonstrated that different $P$. gingivalis LPS isoforms have been reported to have much lower bioactivity, and some of them may antagonize the Toll-like receptors. ${ }^{56}$ In contrast to our results, Yumoto et al. demonstrated an increase in the secretion of IL-8 upon stimulation with periodontal pathogens; ${ }^{57}$ however, in that study the secretion of IL-8 was measured from gingival epithelial cells, and the periodontopathic bacterium Eikenella corrodens was utilized. ${ }^{57}$

Neutrophil recruitment to sites of infection is a critical element of the innate immune response. IL-8 has been the most widely acknowledged neutrophil chemoattractant. ${ }^{46}$ It has been shown that respiratory failure and airway damage in cystic fibrosis patients result from increased production of IL-8, neutrophilic infiltration, and an excessive immune response. ${ }^{45}$ Increased and deregulated recruitment and over- activation of neutrophils have been shown to contribute to tissue damage in chronic inflammatory disorders. In our study IL-8 secretion was inhibited by $P$. gingivalis and $P$. denticola. This reduction of IL-8 may yield an insufficient immune response. We speculate that the ability of these periodontal pathogens to inhibit the secretion of IL-8 may enable the 
bacteria to evade the host response and utilize other virulence factors that lead to the breakdown of the periodontal tissues.

\section{The Secretion of IL-8 and MIP-1 $\alpha$ in the Presence of $F$. nucleatum LPS}

Periodontal disease is not a disease caused by a single periodontal pathogen but rather an interplay between numerous microbiota present in the subgingival plaque and the host responses. Dental plaque is a complex and dynamic microbial community that forms a biofilm on teeth, and harbors more that 700 distinct species $F$. nucleatum is a prominent component quantitatively and is one of the first Gram-negative species to become established in plaque biofilms. ${ }^{19}$ It is a central species in physical interactions between Gram-positive and Gram-negative species that are likely to be important in biofilm colonization, and contributes to the reducing conditions necessary for the emergence of oxygen-intolerant anaerobes. $F$. nucleatum is also consistently associated with, and is increased in number, at sites of periodontitis. However it is not directly responsible for destructive periodontal disease, nor tooth loss. In our study we observed that $F$. nucleatum LPS stimulated the secretion of the tested cytokines, in contrast to $P$. gingivalis and $P$. denticola which inhibited IL-8 and MIP- $1 \alpha$. To better simulate the conditions of a biofilm we tested the response of the monocytes to secrete cytokines in the presence of a challenge from the LPS of $F$. nucleatum combined with either $P$. gingivalis or $P$. denticola LPS. We found that $F$. nucleatum LPS when added to either $P$. gingivalis of $P$. denticola LPS responded by inhibiting the secretion of both IL- 8 and MIP-1 $\alpha$.

There are a few studies in the literature that examine the effects of combining $F$.nucleatum with other periodontal pathogens. Saito et al. demonstrated that F.nucleatum enhances the invasion of $P$. gingivalis in endothelial cells. ${ }^{58}$ This appears to be in accord with what we would expect from the results of our study. However, again it is difficult to compare that study with the results of the present investigation due to difference in the study design.

We further challenged the monocytes with $F$. nucleatum LPS combined with either $P$. gingivalis or $P$. denticola LPS at 15 minute intervals. The results demonstrated an increase in the secretion of both IL- 8 and MIP- $1 \alpha$ cytokines by the monocytes. This appears to indicate that $F$. nucleatum LPS may bind to the same receptor as that of $P$. gingivalis and $P$. denticola. Enabling $F$. nucleatum to block the inhibition of cytokine secretion from the monocytes that was previously demonstrated by both the LPS of $P$. gingivalis and $P$. denticola when added either simultaneously to $F$. nucleatum LPS or independently of $F$. nucleatum LPS. Since periodontal disease is a polymicorobial infection and because $F$. nucleatum is one of the earlier microorganisms isolated from periodontitis. This experiment better simulates what is taking place in vivo in periodontal disease and the results appear to correlate well with the literature which tends to demonstrate an overall increase in the secretion of MIP- $1 \alpha$ and IL- 8 in periodontal disease. $^{40,41,42,44}$ 


\section{LIST OF REFERENCES}

1. Greenspan, J.S. (1994). Orodental diseases. 8th ed. Norwalk, Conn: Appleton and Lange.

2. Paster, B.J., Boches, S.K., Galvin, J.L., Ericson, R.E., Lau, C.N., Levanos, V.A., Sahasrabudhe, A., and Dewhirst, F.E. (2001). Bacterial diversity in human subgingival plaque. J Bacteriol, 183(2), 3770-3783.

3. U.S. Public Health Service, National Institute of Dental Research. (1987). Oral Health of United States Adults: The National Survey of Oral Health in U.S. Employed Adults and Seniors: 1985-1986. National Findings. Bethesda, MD: National Institute of Health, NIH Publication No. NIH-87-2868.

4. Third National Health and Nutrition Examination Survey. (1997). Hyattsville, MD: Centers for Disease Control; 1988-94. Public use data file no. 7-0627.

5. Loe, H. (1993). Periodontal disease: The sixth complication of diabetes. Diabetes Care, 16(1), 329-334.

6. Genco, R., Offenbacher, S., and Beck, J. (2002). Periodontal disease and cardiovascular disease: Epidemiology and possible mechanisms. J Am Dent Assoc, 133(suppl 1), 14-22.

7. Cochran, D.L. (2008). Inflammation and bone loss in periodontal disease. J Periodontol, 79(suppl 8), 1569-1576.

8. Haffajee, A.D., Cugini, M.A., and Tanner, A. (1998). Subgingival microbiota in healthy, well-maintained elder and periodontitis subjects. J Clin Periodontol, 25(5), 346-353.

9. Norskov-Lauritsen, N., and Kilian, M. (2006). Reclassification of Actinobacillus actinomycetemcomitans, Haemophilus aphrophilus. Int J Syst Evol Microbiol, 56(9), 2135-2146.

10. Slots, J. (1986). Bacterial specificity in adult periodontitis. J Clin Periodontol, 13(10), 912-917.

11. Lantz, M.S., Allen, R.D., Duck, L.W., Blume, J.L., Switalski, L.M., and Hook, M. (1991). Identification of Porphyromonas gingivalis components that mediate its interactions with fibronectin. J Bacteriol, 173(14), 4263-4270.

12. Haffajee, A.D., Socransky, S.S., Taubman, M.A., Sioson, J., and Smith, D.J. (1995). Patterns of antibody response in subjects with periodontitis. Oral Microbiol Immunol, 10(3), 129-137. 
13. Cutler, C.W., Arnold, R.R., and Schenkein, H.A. (1993). Inhibition of C3 and IgG proteolysis enhances phagocytosis of Porphyromonas gingivalis. J Immunol, 151(12), 7016-7022.

14. Haffajee, A.D., Bogren, A., Hasturk, H., Feres, M., Lopez, N.J., and Socransky, S.S. (2004). Subgingival microbiota of chronic periodontitis subjects from different geographic locations. J Clin Periodontol, 31(11), 996-1002.

15. Maestre, J.R., Bascones, A., Sánchez, P., Matesanz, P., Aguilar, L., and Giménez, M.J. (2007). Odontogenic bacteria in periodontal disease and resistance patterns to common antibiotics used as treatment and prophylaxis in odontology in Spain. Rev Esp Quimioter, 20(1), 61-67.

16. Listgarten, M.A. (1976). Structure of the microbial flora associated with periodontal health and disease in man. J Periodontol, 47(1), 1-18.

17. Williams, B.L., Pantalone, R.M., and Sherris, J.C. (1976). Subgingival microflora and periodontitis. J Periodontal, 11(1), 1-18.

18. Kolenbrander, P.E., Andersen, R.N., and Moore, L.V. (1989). Coaggregation of Fusobacterium nucleatum, Selenomonas flueggei, Selenomonas infelix, Selenomonas noxia, and Selenomonas sputigena with strains from 11 genera of oral bacteria. Infect Immun, 57(10), 3194-3203.

19. Bradshaw, D.J., Marsh, P.D., Watson, G.K., and Allison, C. (1998). Role of Fusobacterium nucleatum and coaggregation in anaerobe survival in planktonic and biofilm oral microbial communities during aeration. Infect Immun, 66(10), 4729-4732.

20. Genco, R.J. (1992). Host responses in periodontal diseases: Current concepts. J Periodontol, 63(suppl 4), 338-355.

21. Ebersole, J.L. (2003). Humoral immune responses in gingival crevice fluid: Local and systemic implications. Periodontol 2000, 31(1), 135-166.

22. Dixon, D.R., Bainbridge, B.W., and Darveau, R.P. (2004). Modulation of the innate immune response within the periodontium. Periodontol 2000, 35(1), 53-74.

23. Eick, S., Pfister, W., Sigusch, B., and Straube, E. (2000). Phagocytosis of periodontopathogenic bacteria by crevicular granulocytes is depressed in progressive periodontitis. Infection, 28(5), 301-304.

24. Stewart, I., Schluter, P.J., and Shaw, G.R. (2006). Cyanobacterial lipopolysaccharides and human health - a review. Environ Health, 5(7), 13-31. 
25. Page, R.C. (1998). The pathobiology of periodontal diseases may affect systemic diseases: Inversion of a paradigm. Ann Periodontol, 3(1), 108-120.

26. Tobias, P.S., Gegner, J., Tapping, R., and Gegner, J.A. (1997).

Lipopolysaccharide-dependent cellular activation. J Periodont Res, 32(1), 99-103.

27. Kocgozlu, L., Elkaim, R., Tenenbaum, H., and Werner, S. (2009). Variable cell responses to $P$. gingivalis lipopolysaccharide. J Dent Res, 88(8), 741-742.

28. Darveau, R.P., Pham, T.T., Lemley, K., Reife, R.A., Bainbridge, B.W., and Coats, S.R. (2004). Porphyromonas gingivalis lipopolysaccharide contains multiple lipid A species that functionally interact with both Toll-like receptors 2 and 4. Infect Immune, 72(9), 5041-5051.

29. Rife, R.A., Coats S.R., Al-Nqutu, M., Dixon, D.M., Braham, P.A., and Billiard, R.J. (2006). Porphyromonas gingivalis lipopolysaccharide lipid A heterogeneity: Differential activities of tetra- and penta-acylated lipid A structures on E-selectin expression and TLR4 recognition. Cell Microbiol, 8(5), 857-868.

30. Hashimoto, M., Asai, Y., and Ogawa, T. (2004). Separation and structural analysis of lipoprotein in a lipopolysaccharide preparation from Porphyromonas gingivalis. Int Immunol, 16(10), 1431-1437.

31. Hayashi, J., Masaka, T., and Ishikawa, I. (1999). Increased levels of soluble CD14 in sera of periodontitis patients. Infect Immun, 67(1), 417-420.

32. Pussinen, P.J., Paju, S., Mäntylä, P., and Sorsa, T. (2007) Serum microbial- and host-derived markers of periodontal diseases: A review. Curr Med Chem, 14(22), 2402-2412.

33. Raetz, C.R., and Whitfield, C. (2001). Lipopolysaccharide endotoxins. Annu Rev Biochem, 71(9), 635-700.

34. Rittig, M.G. (2004). Smooth and rough lipopolysaccharide phenotypes of Brucella induce different intracellular trafficking and cytokine/chemokine release in human monocytes. J Leuk Biol, 5(4), 196-200.

35. Hancock, R.W., and Reeves, P. (1976). Lipopolysaccharide-deficient, bacteriophage-resistant mutants of Escherichia coli K-12. J Bacteriol, 127(1), 98108.

36. Lerouge, I., and Vanderleyden, J. (2002). O-antigen structural variation: Mechanisms and possible roles in animal/plant-microbe interactions. FEMS Microbiol Rev, 26(1), 17-47. 
37. Sherry, S. (1998). Resolution of the two components of macrophage inflammatory protein 1 , and cloning and characterization of one of those components, macrophage inflammatory protein 1-beta. J Exp Med, 168(6), 22512259.

38. Roodman, G.D. (2006). Regulation of osteoclast differentiation. Ann N Y Acad Sci, 1068(1), 100-109.

39. Choi, S.J., Cruz, J.C., and Craig, F. (2000). Macrophage inflammatory protein-1alpha is a potential osteoclast stimulatory factor in multiple myeloma. Blood, 96(2), 671-675.

40. Silva, T.A., Garlet, G.P., Lara, V.S., Martins, W., Silva, J.S., and Cunha, F.Q. (2005). Differential expression of chemokines and chemokine receptors in inflammatory periapical diseases. Oral Microbiol Immunol, 20(5), 310-316.

41. Garlet, G.P., Martins, W., Ferreira, B.R., Milanezi, C.M., and Silva, J.S. (2003). Patterns of chemokines and chemokine receptors expression in different forms of human periodontal disease. J Periodontal Res, 38(2), 210-217.

42. Fine, D., Markowitz, K., Furgang, D., Fairlie, K., Ferrandiz, J., Nasri, C., McKiernan, M., Donnelly, R., and Gunsolley, J. (2009). Macrophage inflammatory protein-1 $\alpha$ : A salivary biomarker of bone loss in a longitudinal cohort study of children at risk for aggressive periodontal disease. J Periodontol, 80(1), 106-113.

43. Kimata, M., Shichijo, M., Daikoku, M., Inagaki, N., Mori, H., and Nagai, H. (1998). Pharmacological modulation of LPS-induced MIP-1 production by peripheral blood mononuclear cells. Pharmacology, 56(5), 230-236.

44. Ryu, O.H., Choi, S.J., and Linares, A.G. (2007). Gingival epithelial cell expression of macrophage inflammatory protein-1-alpha induced by interleukin1-beta and lipopolysaccharide. J Periodontol, 78(8), 1627-1634.

45. Wolff, B., Burns, A.R., Middleton, J., and Rot, A. (1999). Endothelial cell "memory" of inflammatory stimulation: Human venular endothelial cells store interleukin 8 in Weibel-Palade bodies. J Exp Med, 188(9), 1757-1762.

46. Fitzgerald, J.E., and Kreutzer, D.L. (1995). Localization of interleukin-8 in human gingival tissues. Oral Microbiol Immunol, 10(5), 297-303.

47. McGee, J.M., Tucci, M.A., Edmundson, T.P., Serio, C.L., and Johnson, R.B. (1998). The relationship between concentrations of proinflammatory cytokines within gingiva and the adjacent sulcular depth. J Periodontol, 69(8), 865-871. 
48. Stathopoulou, P.G., Benakanakere, M.R., Galicia, J.C., and Kinane, D.F. (2009). The host cytokine response to Porphyromonas gingivalis is modified by gingipains. Oral Microbiol Immunol, 24(1), 11-17.

49. Westphal, O., and Jann, K. (1965). Bacterial lipopolysaccharides: Extraction with phenol-water and further applications of the procedure. In R.L. Whistler (Ed.), Methods in carbohydrate chemistry, (pp. 83-91). New York: Academic Press Inc.

50. Tsai, C.M., and Frasch, C.E. (1982). A sensitive silver stain of detecting lipopolysaccharides in polyacrylamide gels. Anal Biochem, 119(41), 115-119.

51. Obayashi, T., Tamura, H., Tanaka, S., Ohki, M., Takahashi, S., Arai, M., Masuda, M., and Kawai, T. (1985). A new chromogenic endotoxin-specific assay using recombined limulus coagulation enzymes and its clinical applications. Clinica Chimica Acta, 149(1), 55-65.

52. Tsuchiya, S., Yamabe, M., Yamaguchi, Y., Kobayashi, Y.,Konno, T., and Tada, K. (1980). Establishment and characterization of a human acute monocytic leukemia cell line (THP-1). Int J Cancer, 26(2), 171-176.

53 Rietschel, E.T., Kirikae, T., Schade, F.U., Mamat U., Schmidt, G., Loppnow, H., Ulmer, A.J., Zahinger, U., Seydel, U., Di Padova, F., Schreier, M., and Brade, H. (1994). Bacterial endotoxin: Molecular relationships of the structure to activity and function. FASEB J, 8(2), 217-225.

54. Baggiolini, M., Dewald, B., and Moser, B. (1997). Human chemokines: An update. Annu Rev Immunol, 15(1), 675-705.

55. Hamada, S., Takada, H., Ogawa, T., Fujiwara, T., and Mihura, J. (1990). Lipopolysaccharides of oral anaerobes associated with chronic inflammation: Chemical and immunomodulating properties. Intern Rev Immuno, 6(4), 247-261.

56. Coats, S.R., Jones, J.W., Do, C.T., Braham, P.H., Bainbridge, B.W., To, T.T., Goodlett, D.R., Ernst, R.K., and Darveau, R.P. (2009). Human Toll-like receptor 4 responses to $P$. gingivalis are regulated by lipid A 1- and 4'-phosphatase activities. Cell Microbiol, 11(11), 1587-1599.

57 Yumoto, H., Nakae, H., Fujinaka, K., Ebisu, S., and Matsuo, T. (1999). Interleukin-6 (IL-6) and IL-8 are induced in human oral epithelial cells in response to exposure to periodontopathic Eikenella corrodens. Infect Immun, 67(1), 384-394.

58 Saito, A., Inagaki, S., Kimizuka, R., Okuda, K., Hosaka, Y., Nakagawa, T., and Ishihara, K. (2008). Fusobacterium nucleatum enhances invasion of human gingival epithelial and aortic endothelial cells by Porphyromonas gingivalis. EMS Immunol Med Microbiol, 54(3), 349-355. 


\section{VITA}

Andrew Karl Gray, PharmD., D.D.S. was born in Washington, DC, in the year 1976. He received a Doctor of Pharmacy degree from Howard University College of Pharmacy and Allied Health in 2000. He then received his D.D.S. degree from Howard University College of Dentistry in 2008.

He is currently enrolled as a graduate student in the Department of

Periodontology at The University of Tennessee Health Science Center. He will receive his degree of Masters of Dental Science in May 2011. 